\title{
Voltammetric methods for speciation analysis of trace metals in natural waters
}

\author{
Haitao Han ${ }^{\mathrm{a}, \mathrm{b}}$, Dawei Pan ${ }^{\mathrm{a}, \mathrm{b}, \mathrm{c}, *}$ \\ ${ }^{a}$ CAS Key Laboratory of Coastal Environmental Processes and Ecological Remediation, Shandong Key Laboratory of Coastal Environmental Processes, Research \\ Center for Coastal Environment Engineering Technology of Shandong Province, Yantai Institute of Coastal Zone Research, Chinese Academy of Sciences, Yantai \\ 264003, PR China \\ ${ }^{\mathrm{b}}$ Center for Ocean Mega-Science, Chinese Academy of Sciences, Qingdao 266071, PR China \\ ${ }^{\mathrm{C}}$ University of Chinese Academy of Sciences, Beijing 100049, PR China
}

\section{A R T I C L E I N F O}

\section{Article history:}

Received 14 December 2020

Received in revised form 4 February 2021

Accepted 8 February 2021

\section{Keywords:}

Voltammetry

Speciation analysis

Trace metals

Natural waters

\begin{abstract}
A B S T R A C T
Trace metals play an important role in the regulation of primary productivity and phytoplankton community composition. Metal species directly affects the biogeochemical cycling processes, transport, fate, bioavailability and toxicity of trace metals. Therefore, developing powerful methods for metal speciation analysis is very useful for research in a range of fields, including chemical and environmental analysis. Voltammetric methods, such as anodic stripping voltammetry (ASV) and competing ligand exchange-adsorptive cathodic stripping voltammetry (CLE-AdCSV), have been widely adopted for speciation analysis of metals in different natural aquatic systems. This paper provides an overview of the theory of voltammetric methods and their application for metal speciation analysis in natural waters, with a particular focus on current voltammetric methods for the discrimination of labile/inert fractions, redox species and covalently bound species. Speciation analysis of typical trace metals in natural waters including $\mathrm{Fe}, \mathrm{Cu}, \mathrm{Zn}, \mathrm{Cd}$, and $\mathrm{Pb}$ are presented and discussed in detail, with future perspectives for metal speciation analysis using voltammetric methods also discussed. This review can elaborate the particular knowledge of theory, merits, application and future challenge of voltammetric methods for speciation analysis of trace metals in natural waters.
\end{abstract}

(c) 2021 Elsevier B.V. All rights reserved.

\section{Introduction}

Trace metals, such as iron (Fe), copper ( $\mathrm{Cu})$, zinc $(\mathrm{Zn})$, cadmium $(\mathrm{Cd})$, lead $(\mathrm{Pb})$, chromium $(\mathrm{Cr})$, manganese $(\mathrm{Mn})$, cobalt $(\mathrm{Co})$, nickel (Ni) and molybdenum (Mo), are essential for various biological metabolic processes and biogeochemical cycling in natural waters such as marine, estuary, and freshwater environments [1,2]. Some trace metals, such as $\mathrm{Fe}, \mathrm{Cu}, \mathrm{Zn}, \mathrm{Mn}$, and $\mathrm{Co}$ are responsible for the functioning of metallo-protein enzymes and photosynthetic activity, serving as the limiting factors in primary production $[2,3]$. For example, in $30-40 \%$ of the world oceans, Fe limits the growth of phytoplankton and regulates their community composition, especially in high nutrient-low chlorophyll (HNLC) regions [4-6]. It has also been reported that $\mathrm{Cu}, \mathrm{Zn}, \mathrm{Mn}$, and Co have

\footnotetext{
* Corresponding author at: CAS Key Laboratory of Coastal Environmental Processes and Ecological Remediation, Shandong Key Laboratory of Coastal Environmental Processes, Research Center for Coastal Environment Engineering Technology of Shandong Province, Yantai Institute of Coastal Zone Research, Chinese Academy of Sciences, Yantai 264003, PR China.

E-mail address: dwpan@yic.ac.cn (D. Pan).
}

essential roles in the regulation of phytoplankton community species composition [4,7-9]. However, some metals are toxic to organisms especially when their concentrations exceed a certain threshold $[10,11]$.

Different species of metals have varying chemical and physical properties, affecting their mobility, bioavailability and toxicity $[2,12]$. According to International Union of Pure and Applied Chemistry (IUPAC), speciation is defined as the "distribution of an element amongst defined chemical species in a system", with species classified as a "specific form of an element defined as to isotopic composition, electronic or oxidation state, and/or complex or molecular structure" [13]. The speciation of trace metals in natural waters is usually affected by the surrounding aquatic environment, such as ionic strength, $\mathrm{pH}$, salinity and temperature [14]. Trace metals can be operationally classified as either particulate or dissolved forms (including both dissolved and colloidal species) using membrane filtration $(0.45$ or $0.2 \mu \mathrm{m})$ [15]. Furthermore, dissolved metals can be divided into free ions, inorganically complexed and organically complexed forms. Assessing the form of metal species is essential as this affects the degree of adsorption to suspended matter, the migration rate to sediments 
and overall transport within aquatic systems [16]. For example, researches have shown that compared with the total dissolved concentration, the free ion concentration of metals is more closely related to their bioavailability and toxicity to zooplankton and phytoplankton $[17,18]$.

Dissolved metal species have historically been the main focus of research on trace metals in natural waters. However, the existing forms of dissolved metals are mainly controlled by organic ligands in aquatic systems. The conditional stability constant, $K$, can reflect the strength of metal complexes with organic ligands. According to the complexation strength, organic ligands are generally electrochemically divided into two categories: 1 ) ligands with stronger complexation ability $\left(\mathrm{L}_{1}\right)$, exhibiting $\log K$ values of $12-14$; and 2 ) ligands with weaker complexation ability $\left(\mathrm{L}_{2}\right)$, exhibiting $\log K$ values of $<10[19,20]$. These organic ligands combine with free metal ions, resulting in dissolved metals mainly existing in the form of organic complexes and therefore, reducing their bioavailability. For example, dissolved $\mathrm{Cu}$ is mostly complexed by organic ligands in natural waters, which reduces the fraction of $\mathrm{Cu}$ that is most bioavailable and toxic to organisms $[11,16]$. More than $99 \%$ of Fe in surface seawater exists in an organically complexed form, resulting in the concentration of reactive $\mathrm{Fe}$ in ocean water often being far below the level required for the normal growth of algae $[21,22]$. This phenomenon of "iron limitation" is usually observed in HNLC regions. Studies assessing the effects of oceanic Fe addition have demonstrated that the addition of Fe can promote the growth of algae [5]. However, recent studies have shown that Fe complexed by some small molecule organic compounds, such as exopolymeric substances and siderophores, can also be absorbed and utilized directly by algae [23,24]. Therefore, in an attempt to simplify the classification of dissolved metals, they can be further divided into reactive (labile), inert, acid dissolved and total dissolved forms, according to the water sample pretreatment methods applied [25-27]. Trace metal chemistry regulates the primary productivity and species composition of phytoplankton, with phytoplankton having various feedback effects in response [4]. A diagram of the interactions between trace metals and phytoplankton is shown in Fig. S1. Therefore, speciation analysis of trace metals is essential to understand the biological and geochemical cycling in aquatic systems.

To date, speciation analysis of trace metals has been largely limited by the analytical and sampling methods applied, due to the low concentrations, extreme complexity and heterogeneity of natural water matrices [12,15]. Different strategies have been proposed for speciation analysis of metals to obtain thermodynamic (concentration of elemental forms) and dynamic (nonequilibrium) information [12,28]. Various techniques such as atomic absorption spectroscopy (AAS), atomic emission spectroscopy (AES), inductively coupled plasma-mass spectroscopy (ICPMS), and electrochemical methods have been developed for trace metal analysis [29,30]. Although spectrographic and mass spectrographic techniques exhibit advantages, such as high sensitivity and the potential to be applied to a large number of metals, they can only be used for the analysis of total metal concentrations [31]. To achieve detailed speciation analysis of trace metals, separation and extraction procedures must be coupled with these detection techniques. However, the chemical forms of trace metals are easily changed during separation and extraction steps, with the potential for sample contamination also significantly increased. In contrast, electrochemical techniques are highly suitable for direct metal speciation analysis with minimum sample preparation, reducing the risk of change in speciation or sample contamination, while also allowing in situ application [29,31]. Electrochemical methods are powerful enough to allow the determination of metal species, especially free metal ion concentrations, which is of significance for the assessment of environmental water quality. Based on the assumption that free ions are the only bioavailable species and that toxicity is mainly caused by free ion permeability through biological membranes, two toxicity models have been successfully established, the biotic ligand model (BLM) [32] and the free ion activity model (FIAM) [33]. However, as discussed previously, recent studies have shown that some organically complexed metals can also be absorbed and utilized either directly or through the dissociation of labile complexes [34,35]. Fortunately, kinetic studies of metal complex dissociation on the surface of electrodes can be supported well by the established theory, providing an effective model for the complexation of metals with different ligands and their bioavailability [16].

The use of voltammetry has developed rapidly for the determination and speciation analysis of trace elements in natural waters [12], with stripping methods such as anodic stripping voltammetry (ASV) and cathodic stripping voltammetry (CSV) being sufficiently sensitive for the analysis of trace metals at environmental levels [28]. ASV can determine the total metal concentration and the reactive or labile (ASV-labile) fraction concentration, which is the fraction most relevant to the toxicity or bioavailability of trace metals [36]. CSV can be used for the speciation analysis of a wider range of elements, with the lability of metals defined by their competitive complexation with added and natural ligands. Generally, four fractions of metals can be distinguished using voltammetric methods: free ions, electroactive (reactive or labile), electroinactive (inert or immobile), and total (dissolved) metals [28]. Studies on voltammetric methods for speciation analysis were originally driven by marine research and were subsequently adapted for the analysis of freshwater environments. With continuous development, stripping voltammetry has become the most promising analytical method for speciation analysis of trace metals in natural waters.

Most of the reviews on electrochemical speciation analysis of metal elements are relatively old. The recent published review by Companys et al. in 2017 focuses on the working principles, strong and weak points and applications in environmental media of three selected stripping techniques [34]. This review paper focuses on the speciation analysis of trace metals in natural aquatic environments using voltammetric methods, with an overview of the existing voltammetric methods for speciation analysis of metals presented. The two most commonly used techniques, ASV and competitive ligand exchange-adsorptive cathodic stripping voltammetry (CLE-AdCSV), are reviewed in particular for labile fraction determination and stability parameters. Subsequently, the speciation analysis of typical trace metals including $\mathrm{Cu}, \mathrm{Fe}, \mathrm{Zn}$, $\mathrm{Cd}$ and $\mathrm{Pb}$ in natural waters (especially in seawater) using voltammetric methods is described. Future perspectives for voltammetric analysis of metal speciation in natural waters are also discussed.

\section{Voltammetric methods}

Stripping voltammetry includes two stages: (1) the deposition step, in which the electroactive analyte is accumulated from solution to the electrode surface; (2) the stripping step, in which the analyte is reduced or oxidized back into the solution. The signal to noise ratios $(\mathrm{S} / \mathrm{N})$ can be enhanced by up to four orders of magnitude through the addition of a deposition step prior to a potential scan. Different potential sweep techniques can be adopted for the voltammetric analysis of metals, such as linear sweep voltammetry (LSV), differential pulse voltammetry (DPV) and square wave voltammetry (SWV). DPV and SWV have been used more frequently for metal analysis due to their higher $\mathrm{S} / \mathrm{N}$ providing improved analytical sensitivity. Depending on the reduction or oxidation of analytes during a potential sweep, 
stripping voltammetry can be classed as either ASV (oxidation) or CSV (reduction), with methods based on cathodic stripping (CLEAdCSV and CSV) more commonly used for metal speciation analysis. Other voltammetric methods such as competitive ligand equilibration-anodic stripping voltammetry (CLE-ASV), reverse titration, absence of gradients and Nernstian equilibrium stripping (AGNES), and stripping chronopotentiometry (SCP) can also be used for metal speciation analysis. Fig. 1 shows the imposed/ recorded functions and typical concentration ranges of commonly used voltammetric techniques for speciation analysis of trace metals [31]. Using different sample pretreatment processes, the total (after acidification or UV digestion) and labile metal concentrations can be established by stripping voltammetric methods [28]. Although the free metal ion concentration cannot be directly determined using ASV or CSV, it can be obtained by determining the complexing capacity using the metal titration method.

\subsection{Anodic stripping voltammetry}

ASV is a stripping voltammetric technique that has been widely applied for the determination of different metal species such as $\mathrm{Cu}$, $\mathrm{Pb}, \mathrm{Cd}$, and $\mathrm{Zn}$ in natural waters $[10,25,30,37,38]$. In ASV, a reductive deposition (pre-concentration) step is employed, in which the potential is kept sufficiently negative to accumulate and reduce metal ions onto the working electrode (such as a $\mathrm{Hg}$ electrode) surface. A significant advantage of ASV over other methods is that no pretreatment of water samples is required. The

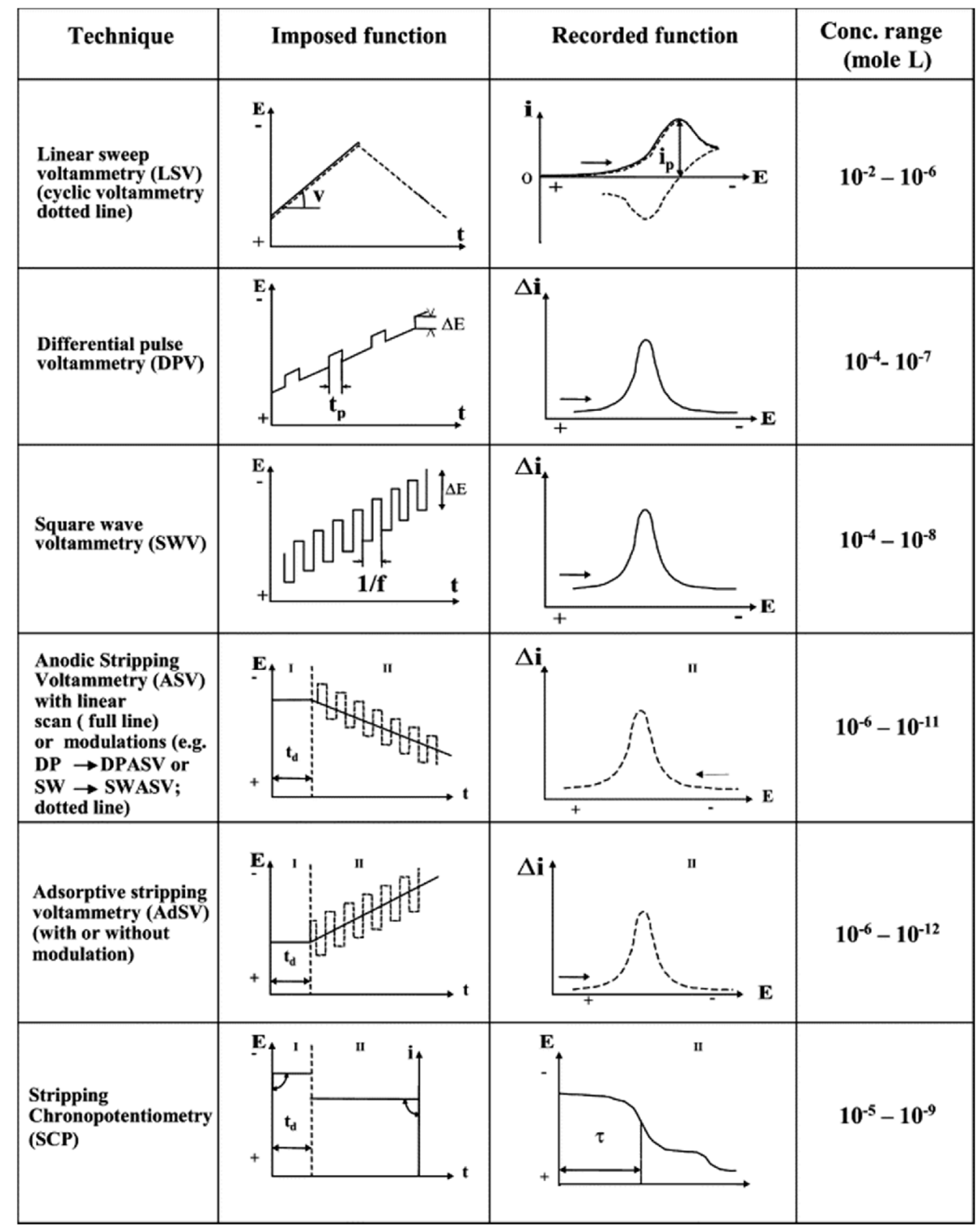

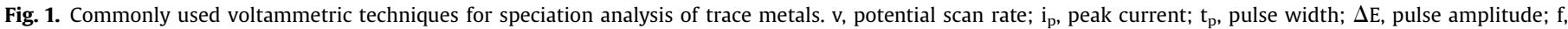
frequency; I, deposition step; II, stripping step; $t_{d}$, accumulation time; $\tau$, transition time. Reprinted with permission from Ref. [31] Copyright (c) 2005 Elsevier. 
concept of 'ASV-labile' species was introduced at the end of 1970's and has subsequently been widely applied for the speciation analysis of trace elements [29]. ASV-labile metals refers to the fraction that can be reduced and accumulated on the electrode (traditionally $\mathrm{Hg}$ electrode), which comprises free metal ions, as well as the inorganically bound and weakly organically bound metals [12]. Hg film electrodes are generally used for ASV determination of metal species in natural waters, especially seawater samples [39-42]. For example, $\mathrm{Hg}$ deposited Iridium (Ir) micro-electrode (array) with gel protective layer is exactly the main working electrode used in voltammetric in situ profiling (VIP) system for real-time monitoring of trace metals [41,42]. The labile fraction of the metal $\mathrm{M}$ is first reduced to $\mathrm{M}^{\circ}$ in the form of a metal amalgam under a given deposition condition (potential and time), then oxidized from the $\mathrm{Hg}$ film into the solution with the oxidation current recorded. The standard addition method is used for the quantification of metals in ASV systems. Hu et al. (2018) investigated the species of $\mathrm{Cu}$ in seawater using ASV, establishing the concentrations of electroactive $\mathrm{Cu}$ (determined directly after filtration), acid-dissolved $\mathrm{Cu}$ (determined after filtration and acidification), inert $\mathrm{Cu}$ (the difference between acid-dissolved and electroactive $\mathrm{Cu}$ ) and total dissolved $\mathrm{Cu}$ (determined after filtration, acidification and UV digestion) [25].

For speciation analysis, metal titration is usually adopted to obtain information about the complexation capacity of ligands L, with the complexation equilibrium obtained after the metal $\mathrm{M}$ is added to the sample using the equilibrium equation shown in Eq. (1):

$$
\mathrm{M}+\mathrm{L} \rightleftarrows \mathrm{ML}
$$

The peak current $\left(i_{\mathrm{p}}\right)$ is considered relatively low when the concentration of $\mathrm{M}\left(c_{\mathrm{M}}\right)$ is less than that of $\mathrm{L}\left(c_{\mathrm{L}}\right)$, increasing proportionally with the increase of free metal ion concentration when $c_{\mathrm{M}}>c_{\mathrm{L}}$. Therefore, a curve can be obtained at $c_{\mathrm{M}} \approx c_{\mathrm{L}}$, allowing the complexation constant $K_{\mathrm{ML}}^{\text {cond }}$ to be obtained from the metal titration data. However, the current response obtained by ASV is contributed by the labile fraction which includes not only free metal ions, but also metal ions dissociated from complexes in the diffusion layer [29]. This makes it very difficult to unambiguously interpret titration curves. Although ASV has high sensitivity for determination of trace metals in natural waters, the adsorption of organics on the working electrode surface may cause interference to the $i_{\mathrm{p}}$. Moreover, when metal titration is used, a long equilibration time of $20-40 \mathrm{~min}$ is needed to equilibrate the added metal ion with natural ligands.

It should be noted that the labile fraction obtained by ASV generally corresponds well with the concentration of bioavailable metals [43-45]. The metals that can be determined by ASV must be capable of being reduced, accumulated and then reoxidized from the electrode surface under appropriate potentials. Therefore, ASV is not suitable for the determination of all trace metals, with some metal elements such as $\mathrm{Fe}$, $\mathrm{Co}$ and $\mathrm{Ni}$ requiring determination using the CSV method [20,46-48].

\subsection{Cathodic stripping voltammetry}

In CSV systems, the metal ions or their complexes are first adsorbed onto the electrode surface, with the potential scan then performed in a negative direction to achieve the reduction of metal ions or complexes. The CSV process with adsorptive preconcentration of metal complexes is referred to as adsorptive CSV (AdCSV). CSV has been widely used for the determination and speciation analysis of metals which cannot be reduced on electrode surface and determined by ASV. Han et al. (2021) determined the Fe concentration in coastal waters using CSV adopting a gold nanoclusters /poly(3,4-ethylenedioxythiophene)poly(sodium 4-styrenesulfonate) modified micro-needle electrode [49]. Zhu et al. (2017) established an AdCSV method for $\mathrm{Fe}$ determination using 2-(5-bromo-2-pyridylazo)-5-diethylaminophenol as the complexing ligand [50]. Subsequently, this method was used for the determination of different Fe species in coastal river water, with analysis of spatial and seasonal Fe species distribution [51].

Currently, CLE-AdCSV, is the most widely used voltammetric method for metal speciation analysis, especially in seawater matrices. The complexation capacity of water samples determined by CLE-AdCSV is a widely employed concept in speciation analysis. The principle of this method is the addition of a well-characterized artificial ligand $(\mathrm{AL})$ with a known complexation constant to the sample, establishing a competitive balance between the AL and natural ligands (L). The electroactive complex between the metal $\mathrm{M}$ and AL is adsorbed on the electrode surface, then reduced and stripped through potential scan. The corresponding equilibration equation is shown in Eq. (2) as follows:

$\mathrm{ML}+\mathrm{AL} \rightleftarrows \mathrm{MAL}+\mathrm{L}$

The electroactive MAL complex can be determined by CSV, with the content of free metal ions $[\mathrm{M}]$ then calculated based on the MAL concentration. CLE-AdCSV has become a widely adopted voltammetric method for investigation of the complexation of different metals by natural ligands [52]. The competitive ligands widely used for metal speciation analysis are listed in Table 1.

Similar to ASV, the concentration of the metal-artificial ligand complex [MAL] can be experimentally determined using metal titration. Using this method, a certain volume of water sample (usually $100-150 \mathrm{~mL}$ ) is mixed with a known concentration of $\mathrm{AL}$

Table 1

Competitive ligands used for CLE-AdCSV spec iation analysis of trace metals.

\begin{tabular}{|c|c|c|}
\hline Competitive ligand & Metals & Reference \\
\hline Tropolone & $\mathrm{Cu}$ & {$[53]$} \\
\hline Benzoylacetone & $\mathrm{Cu}$ & {$[20,54]$} \\
\hline Catechol & $\mathrm{Cu}$ & [55] \\
\hline Salicylaldoxime (SA) & $\mathrm{Cu}, \mathrm{Fe}$ & {$[56,57]$} \\
\hline 8-hydroxyquinoline (Oxine) & $\mathrm{Cu}, \mathrm{Pb}, \mathrm{Cd}$ & {$[58,59]$} \\
\hline 1-nitroso-2-napthol (NN) & $\mathrm{Fe}$ & [60] \\
\hline 2,3-dihydroxynaphthalene (DHN) & $\mathrm{Fe}$ & {$[61]$} \\
\hline 2-(2-thiazolylazo)-p-cresol (TAC) & $\mathrm{Fe}$ & {$[62]$} \\
\hline 1,2-cyclohexanedione dioxime & Co & [63] \\
\hline Dimethylglyoxime (DMG) & Co & [47] \\
\hline DMG & $\mathrm{Ni}$ & {$[48]$} \\
\hline N-nitroso-N-phenylhydroxylamine (Cupferron) & Aluminium (Al) & [64] \\
\hline Calcein-blue (CB) & $\mathrm{Pb}$ & [65] \\
\hline Ammonium pyrrolidine dithiocarbamate (APDC) & $\mathrm{Zn}$ & {$[55,66]$} \\
\hline
\end{tabular}


under suitable $\mathrm{pH}$ conditions, then the solution is divided into 1216 aliquots with increasing concentrations of metal ions added. The concentration of the [MAL] complex is then determined after a set equilibration period. Subsequently, the original ambient speciation of $\mathrm{M}$ in the water sample can be calculated according to the concentration of $[\mathrm{AL}]$ and $[\mathrm{MAL}]$, using the conditional stability constant $K_{\mathrm{MAL}}^{\mathrm{cond}}$ [29]. The strength of the formed complex after the addition of AL can be defined based on its side reaction coefficient as shown in Eq. (3):

$\alpha_{\mathrm{MAL}}=\frac{[\mathrm{MAL}]}{[\mathrm{M}]}=\sum K_{\mathrm{MAL}}^{\mathrm{cond}}[\mathrm{AL}]$

Using this method, the detection window depends on the characteristics and concentration of the added AL. To ensure that the $\alpha_{\text {MAL }}$ remains constant throughout the titration process, the AL should be supplied in excess, typically at least $10^{3}$-fold greater than the $M$ concentration in the water sample [29]. After the [MAL] is determined, the free metal ion concentration $[\mathrm{M}]$ in the presence of AL can be obtained if the $\alpha_{\mathrm{MAL}}$ is known. Considering that only electroactive MAL can be measured by CSV, the side reaction coefficient of AL with M must be within a similar range to that of the natural complexes. Therefore, $\alpha_{\mathrm{MAL}}$ defines the detection window of the method and natural ligands having $\alpha_{\mathrm{ML}}$ values up to about 10 -fold of $\alpha_{\text {MAL }}$ can be detected. If the side reaction coefficients of the complexes are much lower than the detection window, they will be completely decomposed by $\mathrm{AL}$ and the corresponding stability constants cannot be obtained, while the complexes with stronger side reaction coefficients cannot be detected unless the concentration of $\mathrm{AL}$ is increased or it is replaced by a different AL with higher $\alpha_{\mathrm{MAL}}$.

Linear regression and nonlinear regression methods can be used for the fitting of titration data to obtain the required information. Linear fitting methods mainly include the Langmuir/ Ruzic/van den Berg method and the Scatchard method, while the Langmuir method is commonly used for nonlinear fitting [29]. Software can also be used for the processing of titration data, with ProMCC and KMS (KINETEQL Multiwindow Solver) recommended by the GEOTRACES Academic Committee [67,68].

The formation of mixed complexes due to the existence of a continuum of ligands could hinder the interpretation of CLEAdCSV results. Additionally, CLE-AdCSV is an equilibrium technique which requires a sufficient duration (overnight is usually preferred) after addition of the metal or AL into the sample. Internal calibration is widely used for voltammetric determination and speciation analysis of metals, with the sensitivity determined by the upper portion of the titration curve, the slope of which is usually affected by the presence of weak ligands and surface-active material $[29,69]$. In addition, the in situ application of CLE-AdCSV is limited by the necessity for ligand addition, long equilibration times, and the low reliability of most electrodes [29].

\section{Metal species detection using voltammetric methods}

Voltammetric methods can be used to detect different kinds of species of trace metals such as labile/inert fractions, redox species and covalently bound species. The following section discusses the available voltammetric methods for each kind of metal species in detail, especially labile/inert fractions.

\subsection{Labile/inert fractions}

The labile (i.e. reactive or electroactive) metal content is usually expressed as a percentage of the total dissolved metal, with the difference between labile and total metal concentrations attributed to the inert (unreactive, non-electroactive) metal content. An important issue for the determination of labile metals is how well this fraction is defined. In ASV (including ASV titrations), the determination of labile metals that can be reduced and accumulated on the electrode surface, comprises the free metal ions, inorganically bound and weakly organically bound metals. In CSV and CLE-AdCSV analysis, the labile fraction is clearly defined by thermodynamic constraints, referring to the fraction bound to the AL. Voltammetric methods including ASV, CLE-ASV, CSV, CLE-AdCSV, reverse titration, AGNES, and SCP can all be used for the determination of labile fractions.

\subsubsection{Competitive ligand equilibration-adsorptive cathodic stripping voltammetry}

In the CLE-AdCSV procedure, the MAL complex (i.e. the labile fraction) can be directly determined by CSV, resulting in this being the predominantly employed technique for speciation analysis of trace elements in natural waters. The CLE-AdCSV method for speciation analysis of metals is based on attaining an equilibrium between the metal, natural ligands and $\mathrm{AL}$ components. The usually employed overnight ( $14 \mathrm{~h}$ ) equilibration time is the focus of some uncertainty. It has been concluded from coordination chemistry theoretical calculations, that long equilibration times are needed for $\mathrm{Cu}$, Fe and $\mathrm{Ni}$, whereas $\mathrm{Pb}, \mathrm{Cd}$ and $\mathrm{Zn}$ are well within equilibrium conditions when "overnight" equilibration times are applied [12,52].

The development of suitable ALs is another issue that requires further research. It has been reported that CSV can be used for the determination of more than 30 elements, whereas CLE-AdCSV has been developed for the speciation analysis of only 8 elements (Table 1). Therefore, although CLE-AdCSV is widely used for the speciation analysis of trace metals, this method has been applied to a surprisingly limited number of elements. The requirements for long equilibration times, lower concentrations of added ligands and narrow $\mathrm{pH}$ range, might be the main difficulties in converting CSV methods to CLE-AdCSV procedures. A detailed discussion of this phenomenon is presented in a comprehensive review by Monticelli and Caprara [12].

\subsubsection{Anodic stripping voltammetry}

ASV-based metal speciation analysis methods were first introduced over 40 years ago [70]. This method involves a titration process, using increasing amounts of the target metal ion (as described above), with the complexation capacity and conditional stability constant then obtained from titration data. Traditionally, only metal elements that can be reduced on $\mathrm{Hg}$ or $\mathrm{Hg}$ film electrodes to form an amalgam, including $\mathrm{Hg}$ on a solid electrode, are suitable for ASV-based speciation analysis methods [71]. It is assumed that the complexes are inert and do not dissociate during the pre-concentration step [72]. Therefore, to obtain reliable results, a thorough evaluation of the kinetic features of complexes is needed. In addition, the sensitivity of ASV is relatively lower than that of CSV with adsorptive accumulation, which limits its widespread application for the speciation analysis of ultratrace metals. To obtain an operationally defined labile fraction, ASV is also employed without the titration process, establishing a labile fraction concentration under certain deposition conditions (potential and time). Mikkelsen et al. (2006) determined the labile Fe in estuarine and coastal waters by ASV using a silver alloy electrode $(-1.5 \mathrm{~V}$ deposition potential and 300-900 s deposition time) [73]. Furthermore, labile $\mathrm{Cu}$ concentrations in coastal seawater samples were previously determined by ASV using a functional micro-needle electrode with a deposition potential of $-0.3 \mathrm{~V}$ and deposition time of $120 \mathrm{~s}$ [74]. 


\subsubsection{Competitive ligand equilibration-anodic stripping voltammetry}

The competitive ligand equilibration procedure can also be followed by ASV for the detection of labile metals. In this process, the selected AL is added to compete with natural ligands, with metal titration then performed for the detection of labile metal fractions. Through CLE-ASV, the complexation parameters, natural ligand concentration and conditional stability constant can all be obtained using thermodynamic calculations. When the $\mathrm{AL}$ is added, either labile or inert complexes may be formed. If an inert complex is formed, such as ethylenediaminetetraacetic acid (EDTA) for $\mathrm{Zn}$ speciation analysis, the labile fraction detected includes free ion and inorganic forms. In contrast, if a labile complex is formed, the detected labile fraction comprises free ions, inorganic forms and the MAL complex. When ethylenediamine and EDTA are used for $\mathrm{Cu}$ speciation analysis or ethylenediamine for $\mathrm{Cd}$ speciation analysis, labile complexes will be formed. Deposition potentials in excess of $-1.0 \mathrm{~V}$ are usually used for the CLE-ASV speciation analysis of metals. Considering the lower sensitivity compared with CLE-AdCSV and the poorly defined detectable fraction, the CLE-ASV method has been rarely adopted for metal speciation analysis and has only been reported for the analysis of $\mathrm{Cu}, \mathrm{Cd}$ and $\mathrm{Zn}$ speciation [12].

\subsubsection{Reverse titration}

Reverse titration was introduced by Nuester and van den Berg (2005) for the determination of metal speciation [75]. In this method, the natural ligand L is titrated by increasing doses of artificial ligand $\mathrm{AL}$, with measurements performed after equilibrium conditions are obtained (20-30 min). The ligand concentration and conditional stability constant are calculated by linear or nonlinear fitting of the titration data. A typical feature of the reverse titration method is that it can determine the strongest complexing ligands in natural waters, which presents a challenge for standard metal titration methods [75]. In CLE-AdCSV systems, the obtained results are unreliable when $\mathrm{L}$ is saturated by the metal being investigated, whereas the reverse titration method can be employed in this situation. To date, the reverse titration method has been successfully used for the speciation analysis of $\mathrm{Cu}$ and $\mathrm{Fe}$ [75-77].

\subsubsection{Absence of gradients and Nernstian equilibrium stripping}

The AGNES method was introduced in 2004 specifically for the determination of free metal ions [78]. AGNES was initially developed using a hanging mercury drop electrode (HMDE) and subsequently $\mathrm{Hg}$ coated Ir micro-electrodes, screen-printed electrodes and $\mathrm{Hg}$ film electrodes have also been utilized [7981]. Similar to ASV, the AGNES process includes two stages, a deposition step and a stripping step. During the deposition step, a potential is applied for a sufficient duration to obtain the Nernstian equilibrium, at which point there is no concentration gradient between the amalgam and the solution. A pre-concentration factor $Y$ in the amalgam concentration respective to the solution concentration is obtained, which obeys the Nernst law. Subsequently, the metal in the amalgam is stripped through the application of a constant potential and its concentration can be obtained based on the $i$ vs. $t$ function. The application of AGNES to natural waters is usually limited by its detection performance, especially for very low concentration metals. AGNES has been used for the determination of free $\mathrm{Zn}$ ion concentrations in coastal seawater and river water samples [82,83] and it has been shown that free metal ion concentrations obtained using AGNES are in good agreement with those obtained using other procedures [84].

\subsubsection{Stripping chronopotentiometry}

Similar to ASV and AGNES, SCP is a two-step method that includes a deposition step and a stripping step. In the deposition step, metal ions are reduced at a constant potential, in an identical procedure to that of ASV. However, in SCP, a constant oxidizing current is applied to reoxidize the accumulated metals back into solution. SCP measures the change of potential as a function of time, with the main analytical parameter of each signal being the time required for reoxidation or the transition time $(\tau)$, corresponding to two consecutive waves or potential jumps [85]. The transition time can be obtained from integration of the inverse of the time derivative of the potential curve ( $\mathrm{d} t / \mathrm{d} E$ vs. $E$ ), which is proportional to the labile metal concentration [29]. SCP at scanned deposition potentials (SSCP) is the mainly adopted SCP method for metal speciation analysis. The SSCP method consists of SCP measurement of transition times at different deposition potentials. As with ASV, only metals that can be reduced on the electrode can be determined by SCP. Application of the SCP method for environmental analysis and SSCP for dynamic speciation analysis of nanoparticulate metal complexes have been comprehensively reviewed previously $[85,86]$. Table 2 shows the summary of available voltammetric methods for labile fractions determination of some typical trace metals.

\subsection{Redox species}

The toxicity, transfer and adsorption behavior of metal elements are drastically affected by redox state. For example, $\mathrm{Cr}$ (VI) exists in an anionic form (chromate) is highly toxic, while $\mathrm{Cr}$ (III) is non-toxic and exists as anionic or organic species. However, for some other elements such as As and Mn, lower valence states form more toxic species. Therefore, the determination of redox state is an important aspect of metal speciation analysis in natural waters. Voltammetric redox speciation analysis methods are based on the selective determination of a certain oxidation state of an element (which is electroactive). The electroactive labile species concentration is first determined, and then the total metal concentration can be established after converting the inert species into labile species by chemical treatment of the sample. Subsequently, the concentration of the inert redox state of the metal can be calculated based on the difference in measurements. The selection of $\mathrm{pH}$ conditions, addition of complexing agents, and pre-treatment of samples can all be used for the selective determination of specific labile oxidation states of metals. Therefore, voltammetric methods are perfectly suited for the determination of redox species of redox-sensitive metals. Table 3 summarizes the voltammetric methods and the ligands commonly added for redox speciation analysis of trace metals.

Table 2

Available voltammetric methods for the determination of labile fractions of some typical trace metals.

\begin{tabular}{llll}
\hline Voltammetric Methods & Trace Metals & Added ligands & Reference \\
\hline CLE-AdCSV & $\mathrm{Cu}$ & Tropolone, Catechol & {$[53,55]$} \\
& $\mathrm{Fe}$ & NN, DHN, TAC & {$[60-62]$} \\
& $\mathrm{Co}$ & DMG & {$[47]$} \\
& $\mathrm{Ni}$ & DMG & {$[48]$} \\
ASV & $\mathrm{Cu}$ & - & {$[25,74]$} \\
& $\mathrm{Pb}$ & - & {$[87]$} \\
CLE-ASV & $\mathrm{Zn}$ & - & {$[45]$} \\
& $\mathrm{Cu}$ & EDTA & {$[88]$} \\
Reverse titration & $\mathrm{Zn}$ & EDTA & {$[89]$} \\
& $\mathrm{Cd}$ & ethylenediamine & {$[90]$} \\
AGNES & $\mathrm{Cu}$ & SA & {$[76]$} \\
SCP & $\mathrm{Fe}$ & NN & {$[77]$} \\
& $\mathrm{Zn}, \mathrm{Cd}, \mathrm{Pb}$ & - & {$[80]$} \\
& $\mathrm{Cu}$ & - & {$[91]$} \\
& $\mathrm{Hg}$ & - & {$[92]$} \\
\hline
\end{tabular}


Table 3

Voltammetric methods for redox speciation analysis of trace metals.

\begin{tabular}{|c|c|c|c|c|}
\hline Metals & Redox state & Methods & Ligands & Reference \\
\hline \multirow[t]{4}{*}{ Antimony $(\mathrm{Sb})$} & $\mathrm{Sb}(\mathrm{III}) / \mathrm{Sb}(\mathrm{V})$ & ASV & - & [93] \\
\hline & & AdCSV & Chloranilic acid & [94] \\
\hline & & & Catechol & [95] \\
\hline & & & Pyrogallol & [96] \\
\hline \multirow[t]{3}{*}{$\mathrm{Fe}$} & $\mathrm{Fe}(\mathrm{II}) / \mathrm{Fe}(\mathrm{III})$ & AdCSV & NN & [97] \\
\hline & & & 2,2'-dipyridyl (Dp, masking agent) & \\
\hline & & & Bromate (catalyst) & \\
\hline \multirow[t]{2}{*}{$\mathrm{Cr}$} & $\mathrm{Cr}(\mathrm{III}) / \mathrm{Cr}(\mathrm{VI})$ & AdCSV & Diethylenetriaminepentaacetic acid (DTPA) & [98] \\
\hline & & & $\mathrm{NO}_{3}^{-}$(oxidizer) & \\
\hline Thallium ( $\mathrm{Tl})$ & $\mathrm{Tl}(\mathrm{I}) / \mathrm{Tl}(\mathrm{III})$ & ASV & DTPA (masking agent) & [99] \\
\hline \multirow[t]{4}{*}{ Arsenic (As) } & $\mathrm{As}(\mathrm{III}) / \mathrm{As}(\mathrm{V})$ & ASV & - & {$[100]$} \\
\hline & & CSV & - & {$[101]$} \\
\hline & & & Copper & [102] \\
\hline & & & Pyrrolidine dithiocarbamate & [103] \\
\hline
\end{tabular}

\subsection{Covalently bound species}

Covalent binding, such as methylation, has a significant effect on the toxicity of metal elements. To the best of our knowledge, only the direct determination of $\mathrm{Cd}$ and $\mathrm{Hg}$ has been reported for methylated species. By adjusting the $\mathrm{pH}$ of the supporting electrolyte to 8.0, methylcadmium (MeCd) and $\mathrm{Cd}^{2+}$ were determined simultaneously by DPASV using a $\mathrm{Hg}$ film electrode [104]. When a sufficiently long deposition time (30 min) was applied, a high sensitivity could be obtained which was suitable for the determination of $\mathrm{MeCd}$ in uncontaminated marine water. MeHg can be selectively determined by ASV using a nanostructured $\mathrm{Au}$ electrode after $\mathrm{Hg}^{2+}$ is masked by DTPA or reduced by stannous chloride $[105,106]$. The use of voltammetric methods for determination and speciation analysis of $\mathrm{Hg}$ in natural waters has been reviewed in detail previously $[107,108]$. However, since the introduction of gas chromatography-inductively coupled plasmamass spectrometry (GC-ICP-MS), these voltammetric methods have rarely been applied for the determination of covalently bound species, due to the long deposition time requirements [12].

\section{Speciation analysis of typical trace metals in natural waters}

\subsection{Copper}

In previous speciation analysis literature, $\mathrm{Cu}$ is the most widely studied trace metal in freshwater environments [12]. Cu is an essential element for the growth of phytoplankton, while it is toxic to algae and shellfish at free $\mathrm{Cu}^{2+}$ concentration $\left(\left[\mathrm{Cu}^{2+}\right]\right)$ greater than $0.01 \mathrm{nmol} \mathrm{L}^{-1}$, thus inhibiting its growth $[109,110]$. As more than $99 \%$ of $\mathrm{Cu}$ exists in the form of organic complexes, its bioavailability is significantly reduced. As a result, $\left[\mathrm{Cu}^{2+}\right]$ are often considered to be low enough to pose no harm to the ecosystem $[2,111]$. However, recent studies have shown that organically complexed $\mathrm{Cu}$ can also be utilized by some phytoplankton, which indicates that the bioavailability and toxicity of $\mathrm{Cu}$ may be underestimated if only the $\left[\mathrm{Cu}^{2+}\right]$ is considered $[111,112]$. The transformation of different $\mathrm{Cu}$ species and their uptake by plankton and filter feeders is presented in Fig. 2 [113].

Snow and rain sample analysis was conducted using the ASV method by Cheng et al. (1994), with results indicating that the proportion of ASV-labile species was $50 \%$ and $64 \%$ of the total $\mathrm{Cu}$ concentration in snow and rainwater samples, respectively [114]. Speciation analysis of $\mathrm{Cu}$ in a eutrophic lake (Lake Greifen, Switzerland) was performed by Xue et al. (1993) using CLE-AdCSV with catechol as the AL [115], resulting in two classes of ligand being identified, the stronger $\mathrm{L}_{1}\left(\log K_{\mathrm{CuL}} 13.9-14.9\right)$ and the weaker $\mathrm{L}_{2}\left(\log K_{\mathrm{CuL}} 11.8-12.9\right)$. The $\mathrm{Cu}^{2+}$ and total $\mathrm{Cu}$ concentrations were in

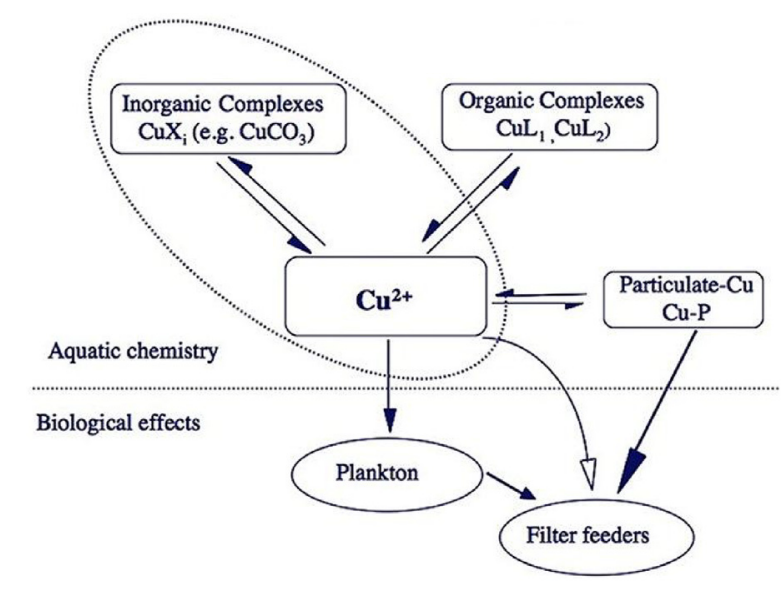

Fig. 2. The speciation, transformation and fate of $\mathrm{Cu}$ in natural waters. Reprinted with permission from Ref. [113] Copyright (c) 2012 American Chemical Society.

the range of $0.1-10 \mathrm{fmol} \mathrm{L}^{-1}$ and $5-28 \mathrm{nmol} \mathrm{L}^{-1}$, respectively, indicating that the $\left[\mathrm{Cu}^{2+}\right]$ was mainly controlled by natural ligands originating from organisms. The strong $\mathrm{Cu}$ ligands in glacial streams have also been determined by CLE-AdCSV using SA as the $\mathrm{AL}$ [116], showing that ligand concentrations and $\log K_{\mathrm{CuL}}$ were in the range of $0.2-8.9 \mathrm{nmol} \mathrm{L}^{-1}$ and $11.51-13.60$, respectively.

$\mathrm{L}_{1}$ and $\mathrm{L}_{2}$ classes of ligands can also be detected in seawater samples [117]. $\mathrm{L}_{1}$ usually exists in surface seawater samples with lower concentrations and $\log K_{\mathrm{CuL}}$ values of $11-14$. Compared to $\mathrm{L}_{1}$, the concentration of $\mathrm{L}_{2}$ is generally relatively high with a uniform vertical distribution. One previous study failed to detect $L_{1}$ ligands in seawater samples from the Atlantic sector of the Southern Ocean, observing only $\mathrm{L}_{2}$ ligands with a relatively uniform distribution [118]. The organic complexation of $\mathrm{Cu}$ was also investigated in surface seawater samples from the Eastern Mediterranean [119]. Evidence has been presented that $\mathrm{Cu}$ can be complexed with humic substances (HS), including humic acid (HA) and fulvic acid (FA) with $\log K_{\mathrm{CuL}}$ value of 12.08 [120,121]. Traditionally, it is widely accepted that $\mathrm{L}_{1}$ ligands in seawater are produced by marine phytoplankton and bacteria $[69,122]$. However, terrigenous HS is another source of $\mathrm{L}_{1}$ ligands in coastal seawater and studies have shown that river parameters have a significant influence on the speciation of $\mathrm{Cu}[123,124]$. It is generally believed that the source of $\mathrm{L}_{2}$ is synthetic ligands transported from freshwater environments to the sea, such as EDTA [125]. In recent years, the speciation of $\mathrm{Cu}$ in a submarine 
hydrothermal environment has also been successfully investigated [126].

\subsection{Iron}

After discovery of the Fe limitation phenomenon, Fe speciation analysis has become a major issue in marine research due to its crucial role in marine biogeochemistry. As shown in Fig. 3, the vertical distribution of Fe in seawater exhibits a typical nutrientlike profile, with low surface concentration and high concentrations in lower regions, with Fe existing in two oxidation states ( $\mathrm{Fe}(\mathrm{II})$ and $\mathrm{Fe}(\mathrm{III})$ ) with different physico-chemical forms [127]. Correspondingly, Fe speciation is commonly investigated by voltammetric methods in terms of redox state and labile fraction concentration.

The oxidation state of Fe can be established using voltammetric methods with $\mathrm{Hg}$ electrodes or solid electrodes and masking reagents [46]. Gledhill and van den Berg (1995) adopted Dp as a masking agent for $\mathrm{Fe}(\mathrm{II})$ to determine $\mathrm{Fe}(\mathrm{III})$ selectively with $\mathrm{NN}$ as the complexing agent and bromate as the oxidizer [97]. Using this method, the concentration of $\mathrm{Fe}(\mathrm{II})$ can be calculated as the difference between the concentrations of Fe determined in the absence and presence of Dp. The redox speciation of Fe in the northern North Sea was investigated using this method, with Fe(II) present at concentrations up to $1.2 \mathrm{nmol} \mathrm{L}^{-1}$. Aldrich et al. (2001) used 2,2'-bipyridyl (Bp) as a masking agent for the selective determination of $\mathrm{Fe}$ (III) [128]. Lin et al. (2016) adopted threedimensional platinum nanoflowers/titanium carbide nanoparticles modified GCE with Bp as the complexing agent for selective determination of $\mathrm{Fe}(\mathrm{II})$ in coastal waters [129]. A Fe ${ }^{2+}$ selective sensor was also fabricated by modifying a carbon screen-printed electrode with polypyrrole and sodium dodecyl sulfate [130]. Labile fractions of Fe have been widely determined using CLEAdCSV methods (see Table 2). Based on the commonly applied CLEAdCSV methods, catalytic enhancement by oxygen was introduced in 2014, achieving a remarkable improvement in sensitivity [57].
The speciation of Fe has been investigated in different natural water samples. Nagai et al. (2008) extensively investigated the speciation of Fe in river water using the CLE-AdCSV method with $\mathrm{NN}$ as the AL [131]. Results showed that Fe concentration and speciation (organic Fe) were controlled by $\mathrm{pH}$ and algal growth, respectively, with the established quantitative model successfully used for the prediction of organically bound Fe concentration based on $\mathrm{pH}$ and algal cell density data. The same method was also used for the Fe speciation analysis in lakes [132]. The results of these studies suggested that Fe might be a limiting factor for phytoplankton communities. Compared with freshwater environments, Fe speciation in seawater has been studied more comprehensively. Abualhaija and van den Berg (2014) studied the chemical speciation of Fe and complex stability of natural ligands in Atlantic seawater samples by CLE-AdCSV with SA as the AL [57]. The concentrations of natural ligands and their conditional stability constants were established across the full water column depth profile of seawater samples collected from the North Atlantic (GEOTRACES GA03), using CLE-AdCSV with SA as the added competitive ligand [133]. Fe binding organic ligands and inorganic Fe concentrations in the West Atlantic Ocean were also investigated using CLE-AdCSV with TAC as a competitive ligand [134]. The speciation of $\mathrm{Fe}$ in samples from the Mersey River estuary and Liverpool Bay was studied using CLE-AdCSV in the presence of SA at multiple analytical windows [135]. Gledhill and Buck (2012) reviewed the organic complexation of $\mathrm{Fe}$ in marine environments in detail, using the CLE-AdCSV method [136].

\subsection{Zinc}

The concentration of dissolved $\mathrm{Zn}$ in open ocean water is generally in the range of $0.05-10 \mathrm{nmol} \mathrm{L}^{-1}$ with vertical distribution patterns exhibiting nutrient-like profiles [137]. $\mathrm{Zn}$ is an essential metal element in metabolic enzymes of phytoplankton and the limitation of reactive $\mathrm{Zn}$ may lead to changes in the phytoplankton community $[17,138]$. Similar to $\mathrm{Cu}$, the speciation of

(A)

(B)
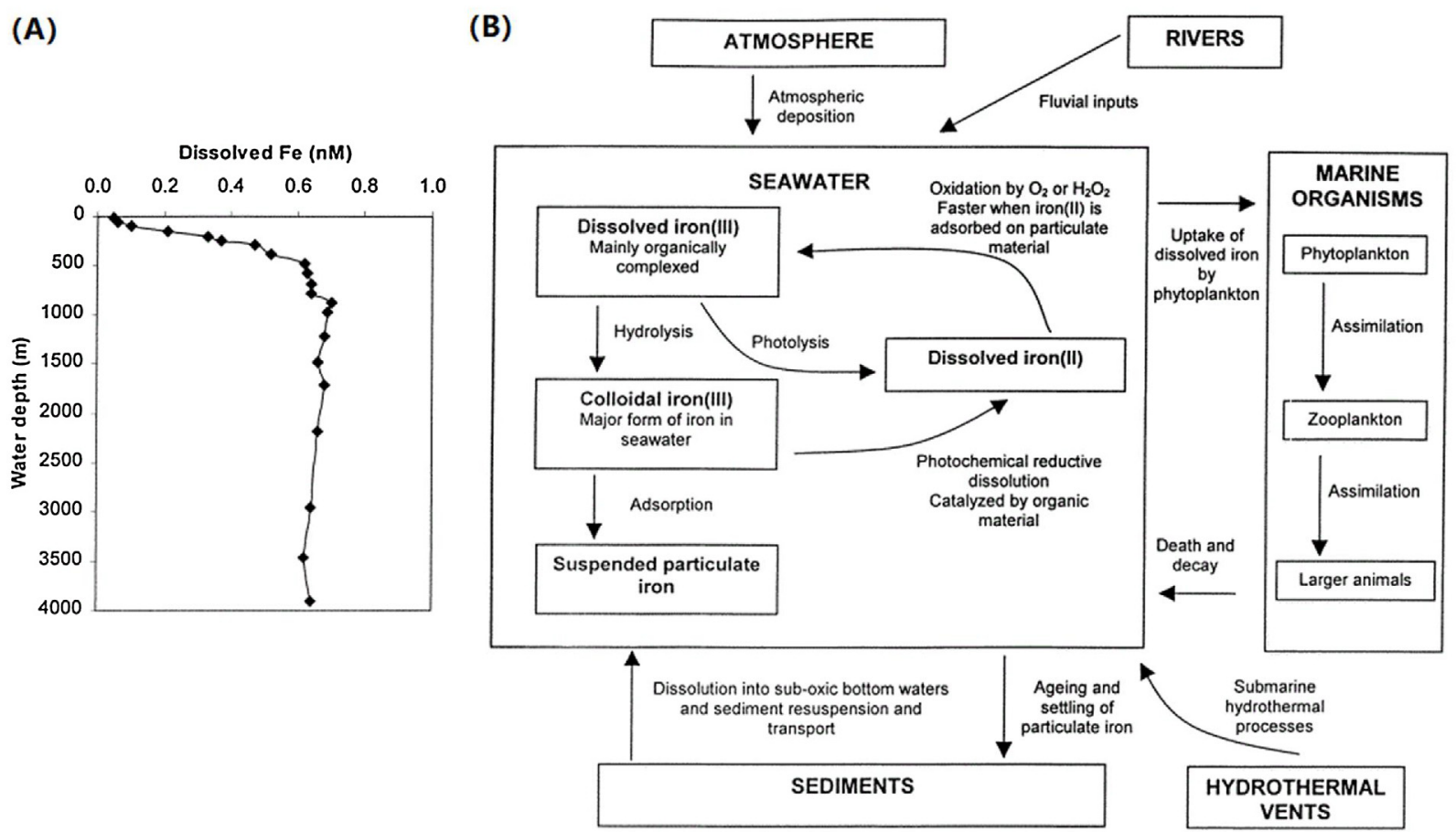

Fig. 3. The typical vertical distribution (A) and biogeochemical cycle process (B) of Fe in seawater. Reprinted with permission from Ref. [127] Copyright (c) 2001 Elsevier. 
Zn can also be determined by ASV and CLE-AdCSV. Considering the low solubility of $\mathrm{Zn}$ in $\mathrm{Hg}$, $\mathrm{Hg}$ film electrodes are generally adopted when the ASV method is used for the direct determination of reactive $\mathrm{Zn}$. The use of $\mathrm{Hg}$ film electrodes can also reduce the reduction of $\mathrm{Zn}$ organic complexes on the electrode surface, increasing the accuracy of determination. CLE-AdCSV has been increasingly used with APDC as the added competitive ligand to improve the detection sensitivity and reproducibility for $\mathrm{Zn}$ speciation analysis [137]. CLE-AdCSV has become the most commonly applied method for Zn speciation analysis in seawater.

High ASV-labile percentages in the range of $76 \%-93 \%$ were found for rain and snow samples [114]. The CLE-AdCSV method was also used for $\mathrm{Zn}$ speciation analysis in lakes, showing that the ligand concentration exceeded total $\mathrm{Zn}$ with $\log K_{\mathrm{ZnL}}$ values in the range of 10.0-11.1 [139]. As a result, the free $\mathrm{Zn}^{2+}$ concentration $\left(\left[\mathrm{Zn}^{2+}\right]\right)$ was very low, in the range of $5-48 \mathrm{pmol} \mathrm{L}^{-1}$, which might be a limiting factor for algal growth. Speciation analysis of $\mathrm{Zn}$ in rivers showed that the ASV-labile $\mathrm{Zn}$ percentage is very variable [140]. ASV-labile $\mathrm{Zn}$ could also be detected in situ using an automated system, generating similar results to diffusive gradients in thin films (DGT) in freshwater [141,142]. The speciation of $Z n$ has also been widely studied in seawater, which has been shown to vary greatly with latitude. In high latitude environments such as the Southern Ocean and western North Pacific, the content of $\mathrm{Zn}$ complex ligand is low, with more dissolved $\mathrm{Zn}$ existing in an inorganic form [137,143]. However, about $98 \%$ of dissolved $\mathrm{Zn}$ in surface seawater at low latitudes is organically complexed, with the concentrations of total dissolved $\mathrm{Zn}$ and ligands all being lower than those in high latitude seawater environments [17,144]. The organic ligands complexed with $\mathrm{Zn}$ in seawater may originate from HS, bacterial secretions, or phytoplankton, which have no relationship with colloidal organic matter [137,145]. The complexes of $\mathrm{Zn}$ with organic ligands in the ocean is strong with $\log K_{\mathrm{ZnL}}$ values in the range of 10-11, while the concentration of $\mathrm{Zn}$ ligands in the marginal sea is higher with relatively lower $\log K_{\mathrm{ZnL}}$ values of about 9.5 [137,144,145].

\subsection{Cadmium}

Cd is an essential element for the growth of phytoplankton which can replace $\mathrm{Zn}$ in biochemical reactions under $\mathrm{Zn}$ limited conditions. However, $\mathrm{Cd}$ is toxic to phytoplankton at high concentrations [146]. The speciation analysis of $\mathrm{Cd}$ in water samples can only be determined using the ASV method with similar parameters to $\mathrm{Zn}[145,147]$. Hg film electrodes are usually suggested as the working electrode for $\mathrm{Cd}$ speciation analysis. The ligand competitive equilibrium method can be combined with ASV to improve the sensitivity of metal speciation analysis when their concentrations are very low. In CLE-ASV, ethylenediamine is widely adopted as the competitive ligand to increase the concentration of reactive Cd complexes [12].

The speciation of $\mathrm{Cd}$ has been studied in fresh and saline waters. In freshwater environments, rivers and lakes have been more comprehensively investigated, with results showing that $\mathrm{Cd}$ speciation is highly regulated by the presence of strong natural organic ligands [148]. The vertical distribution of Cd in oceans exhibits a nutrient-like profile, which suggests that it can be taken up by phytoplankton at the surface and remineralized at lower depths [146]. As a result, the concentration of dissolved $\mathrm{Cd}$ is generally low ( $\mathrm{pmol} \mathrm{L}^{-1}$ levels) in surface seawater environments. The vertical variation in reactive $\mathrm{Cd}$ concentrations is also significant [149]. It has been reported that about $70 \%-99 \%$ of the dissolved $\mathrm{Cd}$ in open ocean surface waters exists in an organically complexed form, while the complexation degree in estuarine and coastal waters ranges from $20 \%-80 \%$ [145,147,150]. Interestingly, almost all of the dissolved Cd exists in reactive form in the South China Sea and northern coastal waters of France [151,152]. The organic ligands of Cd in seawater are usually classified as only one group which can form strong Cd complexes with $\log K_{\mathrm{CdL}}$ values of 9-12 [147]. Humus from marine phytoplankton may be the only source of weak organic ligands for $\mathrm{Cd}$ [145,147].

\subsection{Lead}

$\mathrm{Pb}$ is a highly toxic metal element, which is strongly affected by human activities and is a hazard to human health due to the risk of bioaccumulation [30]. ASV is the main voltammetric method for speciation analysis of $\mathrm{Pb}$ with high sensitivity and good reproducibility. In fresh waters, $\mathrm{CB}$ can be used as the competitive ligand to achieve $\mathrm{Pb}$ speciation analysis by CLE-AdCSV method [65]. In seawater, only the ASV method can be adopted for the determination of $\mathrm{Pb}$ species. $\mathrm{Hg}$ electrodes are commonly utilized for ASV determination of $\mathrm{Pb}$. Considering the toxicity of $\mathrm{Hg}$ and therefore, the difficulty in handling processes, a series of environmentally friendly electrodes such as micro-electrodes have been developed for $\mathrm{Pb}$ speciation analysis [30,153].

A large number of studies on $\mathrm{Pb}$ speciation analysis have been performed on lake or river environments with different degrees of $\mathrm{Pb}$ contamination $[65,140,142,154]$. ASV-labile fractions were found to mostly range from $5 \%-15 \%$ of the total $\mathrm{Pb}$ content, with only a few studies detecting larger labile fraction contributions. The concentration of dissolved $\mathrm{Pb}$ in seawater is usually in the range of $10-80 \mathrm{pmol} \mathrm{L}^{-1}$ with the vertical distribution exhibiting a scavenging-type profile, decreasing with depth [155]. It has been reported that about $55 \%-95 \%$ of $\mathrm{Pb}$ in seawater is organically complexed, which significantly reduces the toxicity of $\mathrm{Pb}$ to marine organisms $[150,156]$. In contrast to $\mathrm{Cu}$, unstable $\mathrm{Pb}$ organic complexes are usually formed, which are readily available for biological uptake and geochemical scavenging [153]. Although two kinds of $\mathrm{Pb}$ ligands have been reported, the organic ligands of $\mathrm{Pb}$ in seawater are generally classified as a single group with $\log K_{\mathrm{PbL}}$ values ranging from 8.5-14 [65,117,150,157].

\subsection{Other metals}

The speciation analysis of other metals such as $\mathrm{Co}, \mathrm{Ni}, \mathrm{Sb}, \mathrm{Al}, \mathrm{Cr}$, $\mathrm{Tl}$ and $\mathrm{As}$, can also be accomplished by voltammetric methods. The determination and speciation analysis of $\mathrm{Co}$ and $\mathrm{Ni}$ are commonly conducted by AdCSV with DMG as the competitive ligand [47,48]. Saito and Moffett (2001) investigated the complexation of Co by natural ligands in the North Atlantic with $\log K_{\text {MAL }}^{\text {cond }}=16.3 \pm 0.9$ obtained [47]. The similar CLE-AdCSV was also adopted for the kinetic studies of Ni speciation in aqueous environmental samples [48]. 1,2-cyclohexanedione dioxime was also reported as competitive ligand for speciation analysis of Co [63]. Different complexing reagents, such as chloranilic acid, catechol and pyrogallol, were adopted for the redox speciation of Sb using AdCSV [94-96]. Quentel and Filella (2002) also determined the inorganic Sb species, $\mathrm{Sb}(\mathrm{III})$ and $\mathrm{Sb}(\mathrm{V})$, in seawater rapidly with ASV [93]. Wang et al. (2001) determined five species (labile monomeric, total monomeric, acid reactive, non-labile monomeric and acid soluble) of $\mathrm{Al}$ in natural waters by AdCSV with solochrome violet RS as complexing reagent [158]. CLE-AdCSV was also used for speciation analysis of $\mathrm{Al}$ to obtain the electroactive fraction and complexing parameters with cupferron as competitive ligand [64]. Bobrowski et al. (2009) reviewed the voltammetric methods for $\mathrm{Cr}$ determination and speciation analysis, focusing on the catalytic AdCSV in the presence of DTPA and nitrate [98]. The redox speciation analysis of $\mathrm{Tl}, \mathrm{Tl}(\mathrm{I})$ and $\mathrm{Tl}(\mathrm{III})$, can be achieved by indirect ASV in the presence of DTPA (masking agent) and acetic buffer [99]. Inorganic As in the environment is of considerable because of its 
toxicity and frequently higher concentration level than the maximum allowable value. ASV and CSV are the two main techniques for the redox speciation analysis of As in natural waters [100,101]. Mays and Hussam (2009) reviewed the voltammetric determination and speciation analysis of inorganic As in the environment in detail [159].

\section{Conclusions and future perspectives}

Trace metals are essential for biological metabolic processes and biogeochemical cycling in natural waters. The toxicity and bioavailability of metals have a closely relationship with their species. The chemical forms of dissolved metals are mainly controlled by organic ligands in natural waters, significantly reducing their bioavailability. Speciation analysis seems to be an important route to study feedback interactions between metals and phytoplankton in natural waters. At present, voltammetric techniques are the most suitable and widely adopted methods for metal speciation analysis with high sensitivity and well-established reaction mechanisms.

This review summarizes the theory and application of voltammetric methods for speciation analysis of trace metals in natural waters. The voltammetric methods including ASV and CLEAdCSV for speciation analysis were discussed in detail. The application of voltammetric methods in discriminating between labile/inert fractions, redox species and covalently bound species was also presented. Determination of labile/inert fractions is one of the most important aspects of metal speciation analysis in natural waters. Different methods such as ASV (CLE-ASV), CSV (CLEAdCSV), reverse titration, AGNES, and SCP can be used for this purpose. Finally, the speciation analysis of typical trace metals including $\mathrm{Fe}, \mathrm{Cu}, \mathrm{Zn}, \mathrm{Cd}$ and $\mathrm{Pb}$ in natural waters (especially seawater) using voltammetric methods was described.

Although voltammetric methods exhibit excellent performance for speciation analysis of a large number of metal ions, there remain some issues and limitations that need to be resolved. The relationship between bioavailability and speciation of metals remains unclear and needs to be further studied. Research in voltammetric speciation analysis of metals is mainly driven by oceanographic scientific studies, and then subsequently adapted to freshwater environments. Compared with seawater, less is known on speciation of trace metals in freshwaters. Furthermore, most speciation analysis of metals is conducted in laboratory environments and there is an urgent demand for new sensing methods and devices that allow in situ and real-time speciation analysis in natural waters.

The development of voltammetric analysis methods and novel working electrodes is also urgently needed. $\mathrm{Hg}$ electrodes such as HMDE and $\mathrm{Hg}$ film electrodes are commonly adopted for determination of different metal species due to their high sensitivity and stability. Considering the toxicity of $\mathrm{Hg}$, it remains necessary to develop novel environmentally friendly electrodes as a substitute for $\mathrm{Hg}$ electrodes. Moreover, strategies to reduce the purging time, complexation time, deposition time and operator time in voltammetric speciation analysis of metals are also required. Finally, to achieve a more detailed and comprehensive description of the speciation of trace metals in natural waters, different complementary analytical methods with specific advantages should be combined effectively.

In summary, voltammetric methods have the potential to be powerful analytical techniques for metal speciation analysis and are likely be developed rapidly in the future. Combining all the improvements discussed in this study, the physicochemical characteristics of trace metals in natural waters established using voltammetric methods can be correlated with bioavailability in interdisciplinary studies. This will result in a more detailed and comprehensive understanding of the relationship between bioavailability and speciation of trace metals in natural water environments.

\section{Declaration of Competing Interest}

The authors declare that they have no known competing financial interests or personal relationships that could have appeared to influence the work reported in this paper.

\section{Acknowledgements}

This work was financially supported by the National Key R\&D Program of China (2019YFD0901103), the Original Innovation Project (ZDBS-LY-DQC009) and Strategic Priority Research Program (XDB42000000) of Chinese Academy of Sciences, and the Shandong Key Laboratory of Coastal Environmental Processes, YICCAS (2019SDHADKFJJ14). We also thank MogoEdit for its linguistic assistance during the preparation of this manuscript.

\section{Appendix A. Supplementary data}

Supplementary material related to this article can be found, in the online version, at doi:https://doi.org/10.1016/j.teac.2021.e00119.

\section{References}

[1] K.A. Hunter, J.P. Kim, P.L. Croot, Biological roles of trace metals in natural waters, Environ. Monit. Assess. 44 (1997) 103-147, doi:http://dx.doi.org/ 10.1023/A:1005720103937.

[2] L. Li, J. Liu, X. Wang, X. Shi, Dissolved trace metal distributions and Cu speciation in the southern Bohai Sea, China, Mar. Chem. 172 (2015) 34-45, doi:http://dx.doi.org/10.1016/j.marchem.2015.03.002.

[3] M.T. Maldonado, A.E. Allen, J.S. Chong, K. Lin, D. Leus, N. Karpenko, S.L. Harris, Copper-dependent iron transport in coastal and oceanic diatoms, Limnol. Oceanogr. 51 (2006) 1729-1743, doi:http://dx.doi.org/10.4319/ lo.2006.51.4.1729.

[4] W.G. Sunda, Feedback interactions between trace metal nutrients and phytoplankton in the ocean, Front. Microbiol. 3 (2012) 204, doi:http://dx.doi. org/10.3389/fmicb.2012.00204.

[5] P.W. Boyd, T. Jickells, C.S. Law, S. Blain, E.A. Boyle, K.O. Buesseler, K.H. Coale, J.J. Cullen, H.J.W. de Baar, M. Follows, M. Harvey, C. Lancelot, M. Levasseur, N.P.J. Owens, R. Pollard, R.B. Rivkin, J. Sarmiento, V. Schoemann, V. Smetacek, S. Takeda, A. Tsuda, S. Turner, A.J. Watson, Mesoscale iron enrichment experiments 1993-2005: synthesis and future directions, Science 315 (2007) 612-617, doi:http://dx.doi.org/10.1126/science.1131669.

[6] J.K. Moorea, S.C. Doney, D.M. Glover, I.Y. Fung, Iron cycling and nutrientlimitation patterns in surface waters of the World Ocean, Deep Sea Res. Part II Top. Stud. Oceanogr. 49 (2002) 463-507, doi:http://dx.doi.org/10.1016/ S0967-0645(01)00109-6.

[7] T.Y. Ho, A. Quigg, Z.V. Finkel, A.J. Milligan, K. Wyman, P.G. Falkowski, F.M.M. Morel, The elemental composition of some marine phytoplankton, J. Phycol. 39 (2003) 1145-1159, doi:http://dx.doi.org/10.1111/j.0022-3646.2003.03090.x.

[8] D.W. Crawford, M.S. Lipsen, D.A. Purdie, M.C. Lohan, P.J. Statham, F.A. Whitney, J.N. Putland, W.K. Johnson, N. Sutherland, T.D. Peterson, P.J. Harrison, C.S. Wong, Influence of zinc and iron enrichments on phytoplankton growth in the northeastern subarctic Pacific, Limnol. Oceanogr. 48 (2003) 1583-1600, doi:http://dx.doi.org/10.4319/ lo.2003.48.4.1583.

[9] M.J. Ellwood, Wintertime trace metal ( $\mathrm{Zn}, \mathrm{Cu}, \mathrm{Ni}, \mathrm{Cd}, \mathrm{Pb}$ and $\mathrm{Co}$ ) and nutrient distributions in the Subantarctic Zone between $40-52^{\circ} \mathrm{S} ; 155-160^{\circ} \mathrm{E}$, Mar. Chem. 112 (2008) 107-117, doi:http://dx.doi.org/10.1016/j. marchem.2008.07.008.

[10] H. Han, D. Pan, S. Zhang, C. Wang, X. Hu, Y. Wang, F. Pan, Simultaneous speciation analysis of trace heavy metals $(\mathrm{Cu}, \mathrm{Pb}, \mathrm{Cd}$ and $\mathrm{Zn})$ in seawater from Sishili Bay, North Yellow Sea, China, Bull. Environ. Contam. Toxicol. 101 (2018) 486-493, doi:http://dx.doi.org/10.1007/s00128-018-2431-4.

[11] R.C. Santore, D.M. Di Toro, P.R. Paquin, H.E. Allen, J.S. Meyer, Biotic ligand model of the acute toxicity of metals. 2. Application to acute copper toxicity in freshwater fish and Daphnia, Environ. Toxicol. Chem. 20 (2001) 23972402, doi:http://dx.doi.org/10.1002/etc.5620201035.

[12] D. Monticelli, S. Caprara, Voltammetric tools for trace element speciation in fresh waters: methodologies, outcomes and future perspectives, Environ. Chem. 12 (2015) 683-705, doi:http://dx.doi.org/10.1071/EN14233.

[13] D.M. Templeton, F. Ariese, R. Cornelis, L.-G. Danielsson, H. Muntau, H.P. Van Leeuwen, R. Łobinski, Guidelines for terms related to chemical speciation and fractionation of elements. Definitions, structural aspects, and 
methodological approaches (IUPAC Recommendations 2000), Pure Appl. Chem. 72 (2000) 1453-1470, doi:http://dx.doi.org/10.1351/ pac200072081453.

[14] M.J. Ellwood, P. Wilson, K. Vopel, M. Green, Trace metal cycling in the Whau Estuary, Auckland, New Zealand, Environ. Chem. 5 (2008) 289-298, doi: http://dx.doi.org/10.1071/EN07077.

[15] R.M. Town, M. Filella, A comprehensive systematic compilation of complexation parameters reported for trace metals in natural waters, Aquat. Sci. 62 (2000) 252-295, doi:http://dx.doi.org/10.1007/PL00001335.

[16] T.M. Florence, Electrochemical approaches to trace element speciation in waters. A review, Analyst 111 (1986) 489-505, doi:http://dx.doi.org/10.1039/ AN9861100489.

[17] M. De Jonge, S. Lofts, L. Bervoets, R. Blust, Relating metal exposure and chemical speciation to trace metal accumulation in aquatic insects under natural field conditions, Sci. Total Environ. 496 (2014) 11-21, doi:http://dx. doi.org/10.1016/j.scitotenv.2014.07.023.

[18] M. Sinoir, M.J. Ellwood, E.C.V. Butler, A.R. Bowie, M. Mongin, C.S. Hassler, Zinc cycling in the Tasman Sea: distribution, speciation and relation to phytoplankton community, Mar. Chem. 182 (2016) 25-37, doi:http://dx.doi. org/10.1016/j.marchem.2016.03.006.

[19] K. Hirose, Conditional stability constants of metal complexes of organic ligands in sea water: past and present, and a simple coordination chemistry model, Anal. Chim. Acta 284 (1994) 621-634, doi:http://dx.doi.org/10.1016/ 0003-2670(94)85067-4

[20] K.W. Bruland, E.L. Rue, J.R. Donat, S.A. Skrabal, J.W. Moffett, Intercomparison of voltammetric techniques to determine the chemical speciation of dissolved copper in a coastal seawater sample, Anal. Chim. Acta 405 (2000) 99-113, doi:http://dx.doi.org/10.1016/S0003-2670(99)00675-3.

[21] R.T. Powell, J.R. Donat, Organic complexation and speciation of iron in the South and Equatorial Atlantic, Deep Sea Res. Part II Top. Stud. Oceanogr. 48 (2001) 2877-2893, doi:http://dx.doi.org/10.1016/S0967-0645(01)00022-4.

[22] H. Su, R. Yang, A. Zhang, Y. Li, Dissolved iron distribution and organic complexation in the coastal waters of the East China Sea, Mar. Chem. 173 (2015) 208-221, doi:http://dx.doi.org/10.1016/j.marchem.2015.03.007.

[23] V. Braun, K. Hantke, Recent insights into iron import by bacteria, Curr. Opin. Chem. Biol. 15 (2011) 328-334, doi:http://dx.doi.org/10.1016/j.cbpa.2011.01.005.

[24] C.S. Hassler, L. Norman, C.A. Mancuso Nichols, L.A. Clementson, C. Robinson, V. Schoemann, R.J. Watson, M.A. Doblin, Iron associated with exopolymeric substances is highly bioavailable to oceanic phytoplankton, Mar. Chem. 173 (2015) 136-147, doi:http://dx.doi.org/10.1016/j.marchem.2014.10.002.

[25] X. Hu, D. Pan, H. Han, C. Wang, Anodic stripping voltammetric analysis of different species of copper in seawater using an electrochemical sensor, J. Oceanogr. 75 (2018) 149-156, doi:http://dx.doi.org/10.1007/s10872-018-0491-z.

[26] A. Annibaldi, S. Illuminati, C. Truzzi, G. Scarponi, SWASV speciation of Cd, Pb and $\mathrm{Cu}$ for the determination of seawater contamination in the area of the Nicole shipwreck (Ancona coast, Central Adriatic Sea), Mar. Pollut. Bull. 62 (2011) 2813-2821, doi:http://dx.doi.org/10.1016/j.marpolbul.2011.08.047.

[27] A.S. Monteiro, C. Parat, A.H. Rosa, J.P. Pinheiro, Towards field trace metal speciation using electroanalytical techniques and tangential ultrafiltration, Talanta 152 (2016) 112-118, doi:http://dx.doi.org/10.1016/j. talanta.2016.01.053.

[28] J. Feldmann, P. Salaün, E. Lombi, Critical review perspective: elemental speciation analysis methods in environmental chemistry - moving towards methodological integration, Environ. Chem. 6 (2009) 275-289, doi:http://dx. doi.org/10.1071/EN09018.

[29] M. Pesavento, G. Alberti, R. Biesuz, Analytical methods for determination of free metal ion concentration, labile species fraction and metal complexation capacity of environmental waters: a review, Anal. Chim. Acta 631 (2009) 129-141, doi:http://dx.doi.org/10.1016/j.aca.2008.10.046.

[30] H. Han, D. Pan, Y. Li, J. Wang, C. Wang, Stripping voltammetric determination of lead in coastal waters with a functional micro-needle electrode, Front. Mar. Sci. 7 (2020) 196, doi:http://dx.doi.org/10.3389/fmars.2020.00196.

[31] J. Buffle, M.L. Tercier-Waeber, Voltammetric environmental trace-metal analysis and speciation: from laboratory to in situ measurements, TrAC Trends Anal. Chem. 24 (2005) 172-191, doi:http://dx.doi.org/10.1016/j. trac.2004.11.013.

[32] S. Niyogi, C.M. Wood, Biotic ligand model, a flexible tool for developing sitespecific water quality guidelines for metals, Environ. Sci. Technol. 38 (2004) 6177-6192, doi:http://dx.doi.org/10.1021/es0496524.

[33] P.L. Brown, S.J. Markich, Evaluation of the free ion activity model of metalorganism interaction: extension of the conceptual model, Aquat. Toxicol. 51 (2000) 177-194, doi:http://dx.doi.org/10.1016/S0166-445X(00)00115-6.

[34] E. Companys, J. Galceran, J.P. Pinheiro, J. Puy, P. Salaün, A review on electrochemical methods for trace metal speciation in environmental media, Curr. Opin. Electrochem. 3 (2017) 144-162, doi:http://dx.doi.org/10.1016/j. coelec.2017.09.007.

[35] C.-M. Zhao, P.G.C. Campbell, K.J. Wilkinson, When are metal complexes bioavailable? Environ. Chem. 13 (2016) 425-433, doi:http://dx.doi.org/ 10.1071/EN15205.

[36] T.M. Florence, Trace element speciation by anodic stripping voltammetry, Analyst 117 (1992) 551-553, doi:http://dx.doi.org/10.1039/AN9921700551.

[37] S. Maity, S.K. Sahu, G.G. Pandit, Determination of traces of $\mathrm{Pb}, \mathrm{Cu}$ and $\mathrm{Cd}$ in seawater around Thane Creek by anodic stripping voltammetry method, Bull. Environ. Contam. Toxicol. 98 (2017) 534-538, doi:http://dx.doi.org/10.1007/ s00128-016-2025-y.
[38] N.M. Thanh, N. Van Hop, N.D. Luyen, N.H. Phong, T.T. Tam Toan, Simultaneous determination of $\mathrm{Zn}(\mathrm{II}), \mathrm{Cd}(\mathrm{II}), \mathrm{Pb}(\mathrm{II})$, and $\mathrm{Cu}(\mathrm{II})$ using differential pulse anodic stripping voltammetry at a bismuth film-modified electrode, Adv. Mater. Sci. Eng. 2019 (2019) 1-11, doi:http://dx.doi.org/10.1155/2019/ 1826148.

[39] S.B. Khoo, S.X. Guo, Rapidly renewable and reproducible mercury film coated carbon paste electrode for anodic stripping voltammetry, Electroanalysis 14 (2001) 813-822, doi:http://dx.doi.org/10.1002/1521-4109(200206) 14:12<813::AID-ELAN813>3.0.CO;2-T.

[40] Z.-L. Lv, G.-M. Qi, T.-J. Jiang, Z. Guo, D.-Y. Yu, J.-H. Liu, X.-J. Huang, A simplified electrochemical instrument equipped with automated flow-injection system and network communication technology for remote online monitoring of heavy metal ions, J. Electroanal. Chem. 791 (2017) 49-55, doi:http://dx.doi. org/10.1016/j.jelechem.2017.03.012.

[41] K.A. Howell, E.P. Achterberg, C.B. Braungardt, A.D. Tappin, D.R. Turner, P.J. Worsfold, The determination of trace metals in estuarine and coastal waters using a voltammetric in situ profiling system, Analyst 128 (2003) 734-741, doi:http://dx.doi.org/10.1039/b300712j.

[42] M.-L. Tercier-Waeber, F. Confalonieri, G. Riccardi, A. Sina, S. Nöel, J. Buffle, F. Graziottin, Multi physical-chemical profiler for real-time in situ monitoring of trace metal speciation and master variables: development, validation and field applications, Mar. Chem. 97 (2005) 216-235, doi:http://dx.doi.org/ 10.1016/j.marchem.2005.03.004.

[43] C. Zhang, L. Li, R. Yang, Research progress on determination of the speciation of dissolved $\mathrm{Cu}, \mathrm{Pb}, \mathrm{Zn}$ and $\mathrm{Cd}$ in seawater by stripping voltammetry, Mar. Environ. Sci. 37 (2018) 151-160.

[44] J.M. Kim, O. Baars, F.M.M. Morel, The effect of acidification on the bioavailability and electrochemical lability of zinc in seawater, Philos. Trans. R. Soc. A 374 (2016)20150296, doi:http://dx.doi.org/10.1098/ rsta.2015.0296.

[45] J.M. Kim, O. Baars, F.M.M. Morel, Bioavailability and electroreactivity of zinc complexed to strong and weak organic ligands, Environ. Sci. Technol. 49 (2015) 10894-10902, doi:http://dx.doi.org/10.1021/acs.est.5b02098.

[46] L.M. Laglera, D. Monticelli, Iron detection and speciation in natural waters by electrochemical techniques: a critical review, Curr. Opin. Electrochem. 3 (2017) 123-129, doi:http://dx.doi.org/10.1016/j.coelec.2017.07.007.

[47] M.A. Saito, J.W. Moffett, Complexation of cobalt by natural organic ligands in the Sargasso Sea as determined by a new high-sensitivity electrochemical cobalt speciation method suitable for open ocean work, Mar. Chem. 75 (2001) 49-68, doi:http://dx.doi.org/10.1016/S0304-4203(01)00025-1.

[48] M.T. Lam, J. Murimboh, N.M. Hassan, C.L. Chakrabarti, Competitive ligand exchange/adsorptive cathodic stripping voltammetry (CLE/AdCSV) for kinetic studies of nickel speciation in aqueous environmental samples containing heterogeneous, macromolecular, organic complexants, Anal. Chim. Acta 402 (1999) 195-209, doi:http://dx.doi.org/10.1016/S0003-2670 (99)00526-7.

[49] H. Han, D. Pan, F. Pan, X. Hu, R. Zhu, A functional micro-needle sensor for voltammetric determination of iron in coastal waters, Sens. Actuators B Chem. 327 (2021) 128883, doi:http://dx.doi.org/10.1016/j.snb.2020.128883.

[50] Y. Zhu, D. Pan, X. Hu, H. Han, M. Lin, C. Wang, An electrochemical sensor based on reduced graphene oxide/gold nanoparticles modified electrode for determination of iron in coastal waters, Sens. Actuators B Chem. 243 (2017) 1-7, doi:http://dx.doi.org/10.1016/j.snb.2016.11.108.

[51] Y. Zhu, X. Hu, D. Pan, H. Han, M. Lin, Y. Lu, C. Wang, R. Zhu, Speciation determination of iron and its spatial and seasonal distribution in coastal river, Sci. Rep. 8 (2018) 2576, doi:http://dx.doi.org/10.1038/s41598-018-20991-0.

[52] H.P. van Leeuwen, R.M. Town, Kinetic limitations in measuring stabilities of metal complexes by competitive ligand exchange-adsorptive stripping voltammetry (CLE-AdSV), Environ. Sci. Technol. 39 (2005) 7217-7225, doi: http://dx.doi.org/10.1021/es050367+.

[53] E.P. Achterberg, C.M.G. van den Berg, M. Boussemart, W. Davison, Speciation and cycling of trace metals in Esthwaite Water: a productive English lake with seasonal deep-water anoxia, Geochim. Cosmochim. Acta 61 (1997) 5233-5253, doi:http://dx.doi.org/10.1016/S0016-7037(97)00316-5.

[54] M.L.A.M. Campos, C.M.G. van den Berg, Determination of copper complexation in sea water by cathodic stripping voltammetry and ligand competition with salicylaldoxime, Anal. Chim. Acta 284 (1994) 481-496, doi: http://dx.doi.org/10.1016/0003-2670(94)85055-0.

[55] C.M.G. van den Berg, P.J.M. Buckley, Z.Q. Huang, M. Nimmo, An electrochemical study of the speciation of copper, zinc and iron in two estuaries in England, Estuar. Coast. Shelf Sci. 22 (1986) 479-486, doi:http:// dx.doi.org/10.1016/0272-7714(86)90069-7.

[56] K.N. Buck, K.W. Bruland, Copper speciation in San Francisco Bay: a novel approach using multiple analytical windows, Mar. Chem. 96 (2005) 185-198, doi:http://dx.doi.org/10.1016/j.marchem.2005.01.001.

[57] M.M. Abualhaija, C.M.G. van den Berg, Chemical speciation of iron in seawater using catalytic cathodic stripping voltammetry with ligand competition against salicylaldoxime, Mar. Chem. 164 (2014) 60-74, doi: http://dx.doi.org/10.1016/j.marchem.2014.06.005.

[58] M. Nimmo, G.R. Fones, R. Chester, Atmospheric deposition: a potential source of trace metal organic complexing ligands to the marine environment, Croat. Chem. Acta 71 (1998) 323-341.

[59] L. Jin, N.J. Gogan, Copper complexing capacities of freshwaters by adsorptive cathodic stripping voltammetry, Anal. Chim. Acta 412 (2000) 77-88, doi: http://dx.doi.org/10.1016/S0003-2670(00)00763-7. 
[60] M. Gledhill, C.M.G. van den Berg, Determination of complexation of iron(III) with natural organic complexing ligands in seawater using cathodic stripping voltammetry, Mar. Chem. 47 (1994) 41-54, doi:http://dx.doi.org/10.1016/ 0304-4203(94)90012-4.

[61] C.M.G. van den Berg, Chemical speciation of iron in seawater by cathodic stripping voltammetry with dihydroxynaphthalene, Anal. Chem. 78 (2006) 156-163, doi:http://dx.doi.org/10.1021/ac051441+.

[62] P.L. Croot, M. Johansson, Determination of iron speciation by cathodic stripping voltammetry in seawater using the competing ligand 2-(2Thiazolylazo)-p-cresol (TAC), Electroanalysis 12 (2000) 565-576, doi:http:// dx.doi.org/10.1002/(SICI)1521-4109(200005)12:8<565::AID-ELAN565>3.0. $\mathrm{CO} ; 2-\mathrm{L}$

[63] M.J. Ellwood, C.M.G. van den Berg, Determination of organic complexation of cobalt in seawater by cathodic stripping voltammetry, Mar. Chem. 75 (2001) 33-47, doi:http://dx.doi.org/10.1016/S0304-4203(01)00024-X.

[64] A. Magnier, V. Fekete, J. Van Loco, F. Bolle, M. Elskens, Speciation study of aluminium in beverages by competitive ligand exchange-adsorptive stripping voltammetry, Talanta 122 (2014) 30-35, doi:http://dx.doi.org/ 10.1016/j.talanta.2013.12.051.

[65] E. Fischer, C.M.G. van den Berg, Determination of lead complexation in lake water by cathodic stripping voltammetry and ligand competition, Anal. Chim. Acta 432 (2001) 11-20, doi:http://dx.doi.org/10.1016/S0003-2670(00) 01353-2.

[66] C.M.G. van den Berg, Determination of the zinc complexing capacity in seawater by cathodic stripping voltammetry of zinc-APDC complex ions, Mar. Chem. 16 (1985) 121-130, doi:http://dx.doi.org/10.1016/0304-4203(85) 90017-9.

[67] D. Omanović, C. Garnier, I. Pižeta, ProMCC: an all-in-one tool for trace metal complexation studies, Mar. Chem. 173 (2015) 25-39, doi:http://dx.doi.org/ 10.1016/j.marchem.2014.10.011.

[68] I. Pižeta, S.G. Sander, R.J.M. Hudson, D. Omanović, O. Baars, K.A. Barbeau, K.N. Buck, R.M. Bundy, G. Carrasco, P.L. Croot, C. Garnier, L.J.A. Gerringa, M. Gledhill, K. Hirose, Y. Kondo, L.M. Laglera, J. Nuester, M.J.A. Rijkenberg, S. Takeda, B.S. Twining, M. Wells, Interpretation of complexometric titration data: an intercomparison of methods for estimating models of trace metal complexation by natural organic ligands, Mar. Chem. 173 (2015) 3-24, doi: http://dx.doi.org/10.1016/j.marchem.2015.03.006.

[69] B.M. Voelker, M.B. Kogut, Interpretation of metal speciation data in coastal waters: the effects of humic substances on copper binding as a test case, Mar. Chem. 74 (2001) 303-318, doi:http://dx.doi.org/10.1016/S0304-4203(01) 00022-6.

[70] Y.K. Chau, R. Gächter, K. Lum-Shue-Chan, Determination of the apparent complexing capacity of lake waters, J. Fish Res. Board Can. 31 (1974) 15151519, doi:http://dx.doi.org/10.1139/f74-182.

[71] Q. Wu, S.C. Apte, G.E. Batley, K.C. Bowles, Determination of the mercury complexation capacity of natural waters by anodic stripping voltammetry, Anal. Chim. Acta 30 (1997) 129-134, doi:http://dx.doi.org/10.1016/S00032670(97)00327-9.

[72] A.M. Mota, J.P. Pinheiro, M.L. Simoes Goncalves, Electrochemical methods for speciation of trace elements in marine waters. Dynamic aspects, J. Phys. Chem. A 116 (2012) 6433-6442, doi:http://dx.doi.org/10.1021/jp2124636.

[73] Ø. Mikkelsen, C.M.G. van den Berg, K.H. Schrøder, Determination of labile iron at low nmol L $\mathrm{L}^{-1}$ levels in estuarine and coastal waters by anodic stripping voltammetry, Electroanalysis 18 (2006) 35-43, doi:http://dx.doi.org/ 10.1002/elan.200503360.

[74] H. Han, W. Tao, X. Hu, X. Ding, D. Pan, C. Wang, S. Xu, Needle-shaped electrode for speciation analysis of copper in seawater, Electrochim. Acta 289 (2018) 474-482, doi:http://dx.doi.org/10.1016/j.electacta.2018.08.097.

[75] J. Nuester, C.M.G. van den Berg, Determination of metal speciation by reverse titrations, Anal. Chem. 77 (2005) 11-19, doi:http://dx.doi.org/10.1021/ ac049078e.

[76] J. Santos-Echeandía, L.M. Laglera, R. Prego, C.M.G. van den Berg, Copper speciation in estuarine waters by forward and reverse titrations, Mar. Chem. 108 (2008) 148-158, doi:http://dx.doi.org/10.1016/j.marchem.2007.11.004.

[77] J.A. Hawkes, M. Gledhill, D.P. Connelly, E.P. Achterberg, Characterisation of iron binding ligands in seawater by reverse titration, Anal. Chim. Acta 766 (2013) 53-60, doi:http://dx.doi.org/10.1016/j.aca.2012.12.048.

[78] J. Galceran, E. Companys, J. Puy, J. Cecilia, J.L. Garces, AGNES: a new electroanalytical technique for measuring free metal ion concentration, J. Electroanal. Chem. 566 (2004) 95-109, doi:http://dx.doi.org/10.1016/j. jelechem.2003.11.017.

[79] C. Huidobro, E. Companys, J. Puy, J. Galceran, J.P. Pinheiro, The use of microelectrodes with AGNES, J. Electroanal. Chem. 606 (2007) 134-140, doi: http://dx.doi.org/10.1016/j.jelechem.2007.06.001.

[80] C. Parat, D. Aguilar, L. Authier, M. Potin-Gautier, E. Companys, J. Puy, J. Galceran, Determination of free metal ion concentrations using screenprinted electrodes and AGNES with the charge as response function, Electroanalysis 23 (2011) 619-627, doi:http://dx.doi.org/10.1002/ elan.201000566.

[81] L.S. Rocha, E. Companys, J. Galceran, H.M. Carapuca, J.P. Pinheiro, Evaluation of thin mercury film rotating disk electrode to perform absence of gradients and Nernstian equilibrium stripping (AGNES) measurements, Talanta 80 (2010) 1881-1887, doi:http://dx.doi.org/10.1016/j.talanta.2009.10.038.

[82] J. Galceran, C. Huidobro, E. Companys, G. Alberti, AGNES: a technique for determining the concentration of free metal ions. The case of $\mathrm{Zn}(\mathrm{II})$ in coastal
Mediterranean seawater, Talanta 71 (2007)1795-1803, doi:http://dx.doi.org/ 10.1016/j.talanta.2006.08.027.

[83] F. Zavarise, E. Companys, J. Galceran, G. Alberti, A. Profumo, Application of the new electroanalytical technique AGNES for the determination of free $\mathrm{Zn}$ concentration in river water, Anal. Bioanal. Chem. 397 (2010) 389-394, doi: http://dx.doi.org/10.1007/s00216-009-3439-8.

[84] G. Alberti, R. Biesuz, C. Huidobro, E. Companys, J. Puy, J. Galceran, A comparison between the determination of free $\mathrm{Pb}$ (II) by two techniques: absence of gradients and Nernstian equilibrium stripping and resin titration, Anal. Chim. Acta 599 (2007) 41-50, doi:http://dx.doi.org/10.1016/j. aca.2007.07.055.

[85] N. Serrano, J.M. Díaz-Cruz, C. Ariño, M. Esteban, Stripping chronopotentiometry in environmental analysis, Electroanalysis 19 (2007) 2039-2049, doi:http://dx.doi.org/10.1002/elan.200703956.

[86] R.M. Town, H.P. van Leeuwen, Stripping chronopotentiometry at scanned deposition potential (SSCP): an effective methodology for dynamic speciation analysis of nanoparticulate metal complexes, J. Electroanal. Chem. 853 (2019) 113530, doi:http://dx.doi.org/10.1016/j.jelechem.2019.113530.

[87] J.M. Antelo, F. Arce, F.J. Penedo, Levels and speciation of heavy metals in unpolluted river water, Toxicol. Environ. Chem. 58 (2008) 143-149, doi: http://dx.doi.org/10.1080/02772249709358404.

[88] R. Wang, C.L. Chakrabarti, Copper speciation by competing ligand exchange method using differential pulse anodic stripping voltammetry with ethylenediaminetetraacetic acid (EDTA) as competing ligand, Anal. Chim. Acta 614 (2008) 153-160, doi:http://dx.doi.org/10.1016/j.aca.2008.03.007.

[89] H.B. Xue, L. Sigg, Zinc speciation in lake waters and its determination by ligand exchange with EDTA and differential pulse anodic stripping voltammetry, Anal. Chim. Acta 284 (1994) 505-515, doi:http://dx.doi.org/ 10.1016/0003-2670(94)85057-7.

[90] H. Xue, L. Sigg, Cadmium speciation and complexation by natural organic ligands in fresh water, Anal. Chim. Acta 363 (1998) 249-259, doi:http://dx doi.org/10.1016/S0003-2670(98)00081-6.

[91] J. Wang, N. Foster, S. Armalis, D. Larson, A. Zirino, K. Olsen, Remote stripping electrode for in situ monitoring of labile copper in the marine environment, Anal. Chim. Acta 310 (1995) 223-231, doi:http://dx.doi.org/10.1016/00032670(95)00155-S.

[92] M.A. Augelli, R.A. Abarza Munoz, E.M. Richter, A. Gouveia Junior, L. Angnes, Chronopotentiometric stripping analysis using gold electrodes, an afficient technique for mercury quantification in natural waters, Electroanalysis 17 (2005) 755-761, doi:http://dx.doi.org/10.1002/elan.200403156.

[93] F. Quentel, M. Filella, Determination of inorganic antimony species in seawater by differential pulse anodic stripping voltammetry: stability of the trivalent state, Anal. Chim. Acta 452 (2002) 237-244, doi:http://dx.doi.org/ 10.1016/S0003-2670(01)01474-X.

[94] W. Wagner, S. Sander, G. Henze, Trace analysis of antimony(III) and antimony (V) by adsorptive stripping voltammetry, Fresenius J. Anal. Chem. 354 (1996) 11-15, doi:http://dx.doi.org/10.1007/s002169600002.

[95] C.M.G. van den Berg, S.H. Khan, P.J. Daly, J.P. Riley, D.R. Turner, An electrochemical study of $\mathrm{Ni}, \mathrm{Sb}, \mathrm{Se}, \mathrm{Sn}, \mathrm{U}$ and $\mathrm{V}$ in the estuary of the tamar, Estuar. Coast. Shelf Sci. 33 (1991) 309-322, doi:http://dx.doi.org/ 10.1016/0272-7714(91)90059-K.

[96] M.J. Gomez Gonzalez, O. Dominguez Renedo, M.J. Arcos Martinez, Speciation of antimony by adsorptive stripping voltammetry using pyrogallol, Talanta 71 (2007) 691-698, doi:http://dx.doi.org/10.1016/j. talanta.2006.05.025.

[97] M. Gledhill, C.M.G. van den Berg, Measurement of the redox speciation of iron in seawater by catalytic cathodic stripping voltammetry, Mar. Chem. 50 (1995) 51-61, doi:http://dx.doi.org/10.1016/0304-4203(95)00026-N.

[98] A. Bobrowski, A. Królicka, J. Zarebski, Characteristics of voltammetric determination and speciation of chromium-A review, Electroanalysis 21 (2009) 1449-1458, doi:http://dx.doi.org/10.1002/elan.200904582.

[99] B. Krasnodębska-Ostręga, J. Pałdyna, M. Wawrzyńska, E. Stryjewska, Indirect anodic stripping voltammetric determination of $\mathrm{Tl}(\mathrm{I})$ and $\mathrm{Tl}(\mathrm{III})$ in the Baltic seawater samples enriched in Thallium species, Electroanalysis 23 (2010) 605-610, doi:http://dx.doi.org/10.1002/elan.201000399.

[100] X. Dai, O. Nekrassova, M.E. Hyde, R.G. Compton, Anodic stripping voltammetry of arsenic(III) using gold nanoparticle-modified electrodes, Anal. Chem. 76 (2004) 5924-5929, doi:http://dx.doi.org/10.1021/ac049232x.

[101] K. Gibbon-Walsh, P. Salaun, C.M. van den Berg, Arsenic speciation in natural waters by cathodic stripping voltammetry, Anal. Chim. Acta 662 (2010) 1-8, doi:http://dx.doi.org/10.1016/j.aca.2009.12.038.

[102] M.A. Ferreira, A.A. Barros, Determination of As(III) and $\operatorname{arsenic}(\mathrm{V})$ in natural waters by cathodic stripping voltammetry at a hanging mercury drop electrode, Anal. Chim. Acta 459 (2002) 151-159, doi:http://dx.doi.org/ 10.1016/S0003-2670(02)00086-7.

[103] J. Zima, C.M.G. van den Berg, Determination of arsenic in sea water by cathodic stripping voltammetry in the presence of pyrrolidine dithiocarbamate, Anal. Chim. Acta 289 (1994) 291-298, doi:http://dx.doi. org/10.1016/0003-2670(94)90004-T.

[104] R. Pongratz, K.G. Heumann, Determination of monomethylcadmium in the environment by differential pulse anodic stripping voltammetry, Anal. Chem. 68 (1996) 1262-1266, doi:http://dx.doi.org/10.1021/ac9507911.

[105] M. Korolczuk, I. Rutyna, New methodology for anodic stripping voltammetric determination of methylmercury, Electrochem. commun. 10 (2008) 10241026, doi:http://dx.doi.org/10.1016/j.elecom.2008.04.033. 
[106] O. Abollino, A. Giacomino, M. Malandrino, S. Marro, E. Mentasti, Voltammetric determination of methylmercury and inorganic mercury with an home made gold nanoparticle electrode, J. Appl. Electrochem. 39 (2009) 2209-2216, doi:http://dx.doi.org/10.1007/s10800-009-9830-5.

[107] C. Gao, X.-J. Huang, Voltammetric determination of mercury(II), TrAC Trends Anal. Chem. 51 (2013) 1-12, doi:http://dx.doi.org/10.1016/j.trac.2013.05.010.

[108] K. Leopold, M. Foulkes, P. Worsfold, Methods for the determination and speciation of mercury in natural waters-A review, Anal. Chim. Acta 663 (2010) 127-138, doi:http://dx.doi.org/10.1016/j.aca.2010.01.048.

[109] J.W. Moffett, L.E. Brand, P.L. Croot, K.A. Barbeau, Cu speciation and cyanobacterial distribution in harbors subject to anthropogenic $\mathrm{Cu}$ inputs, Limnol. Oceanogr. 42 (1997) 789-799, doi:http://dx.doi.org/10.4319/ lo.1997.42.5.0789.

[110] L.E. Brand, W.G. Sunda, R.R.L. Guillard, Reduction of marine phytoplankton reproduction rates by copper and cadmium, J. Exp. Mar. Biol. Ecol. 96 (1986) 225-250, doi:http://dx.doi.org/10.1016/0022-0981(86)90205-4.

[111] K.N. Buck, K.E. Selph, K.A. Barbeau, Iron-binding ligand production and copper speciation in an incubation experiment of Antarctic Peninsula shelf waters from the Bransfield Strait, Southern Ocean, Mar. Chem. 122 (2010) 148-159, doi:http://dx.doi.org/10.1016/j.marchem.2010.06.002.

[112] D.M. Semeniuk, R.M. Bundy, C.D. Payne, K.A. Barbeau, M.T. Maldonado, Acquisition of organically complexed copper by marine phytoplankton and bacteria in the northeast subarctic Pacific Ocean, Mar. Chem. 173 (2015) 222233, doi:http://dx.doi.org/10.1016/j.marchem.2015.01.005.

[113] K. Ndungu, Model predictions of copper speciation in coastal water compared to measurements by analytical voltammetry, Environ. Sci. Technol. 46 (2012) 7644-7652, doi:http://dx.doi.org/10.1021/es301017x.

[114] J. Cheng, C.L. Chakrabarti, M.H. Back, W.H. Schroeder, Chemical speciation of $\mathrm{Cu}, \mathrm{Zn}, \mathrm{Pb}$ and $\mathrm{Cd}$ in rain water, Anal. Chim. Acta 288 (1994) 141-156, doi: http://dx.doi.org/10.1016/0003-2670(94)80128-2.

[115] H. Xue, L. Sigg, Free cupric ion concentration and $\mathrm{Cu}(\mathrm{II})$ speciation in a eutrophic lake, Limnol. Oceanogr. 38 (1993) 1200-1213, doi:http://dx.doi. org/10.4319/lo.1993.38.6.1200.

[116] D. Monticelli, A. Pozzi, A. Credaro, C. Dossi, An electroanalytical approach to the understanding of copper exportation in Glaciated Catchments, Electroanalysis 24 (2012) 807-812, doi:http://dx.doi.org/10.1002/ elan.201100560.

[117] P.B. Kozelka, K.W. Bruland, Chemical speciation of dissolved $\mathrm{Cu}, \mathrm{Zn}, \mathrm{Cd}, \mathrm{Pb}$ in Narragansett Bay, Rhode Island, Mar. Chem. 60 (1998) 267-282, doi:http:// dx.doi.org/10.1016/S0304-4203(97)00107-2.

[118] M.I. Heller, P.L. Croot, Copper speciation and distribution in the Atlantic sector of the Southern Ocean, Mar. Chem. 173 (2015) 253-268, doi:http://dx. doi.org/10.1016/j.marchem.2014.09.017.

[119] S. Karavoltsos, E. Kalambokis, A. Sakellari, M. Plavšić, E. Dotsika, P. Karalis, L. Leondiadis, M. Dassenakis, M. Scoullos, Organic matter characterization and copper complexing capacity in the sea surface microlayer of coastal areas of the Eastern Mediterranean, Mar. Chem. 173 (2015) 234-243, doi:http://dx. doi.org/10.1016/j.marchem.2014.12.004.

[120] H. Whitby, C.M.G. van den Berg, Evidence for copper-binding humic substances in seawater, Mar. Chem. 173 (2015) 282-290, doi:http://dx.doi. org/10.1016/j.marchem.2014.09.011.

[121] M.M. Abualhaija, H. Whitby, C.M.G. van den Berg, Competition between copper and iron for humic ligands in estuarine waters, Mar. Chem. 172 (2015) 46-56, doi:http://dx.doi.org/10.1016/j.marchem.2015.03.010.

[122] F.L.L. Muller, S. Jacquet, W.H. Wilson, Biological factors regulating the chemical speciation of $\mathrm{Cu}, \mathrm{Zn}$, and $\mathrm{Mn}$ under different nutrient regimes in a marine mesocosm experiment, Limnol. Oceanogr. 48 (2003) 2289-2302, doi: http://dx.doi.org/10.4319/lo.2003.48.6.2289.

[123] F.L.L. Muller, S. Batchelli, Copper binding by terrestrial versus marine organic ligands in the coastal plume of River Thurso, North Scotland, Estuar. Coast. Shelf Sci. 133 (2013) 137-146, doi:http://dx.doi.org/10.1016/j. ecss.2013.08.024.

[124] G.R. Aiken, H. Hsu-Kim, J.N. Ryan, Influence of dissolved organic matter on the environmental fate of metals, nanoparticles, and colloids, Environ. Sci. Technol. 45 (2011) 3196-3201, doi:http://dx.doi.org/10.1021/es103992s.

[125] M. Plavšić, B. Gašparović, S. Strmečki, V. Vojvodić, N. Tepić, Copper complexing ligands and organic matter characterization in the northern Adriatic Sea, Estuar. Coast. Shelf Sci. 85 (2009) 299-306, doi:http://dx.doi. org/10.1016/j.ecss.2009.08.014.

[126] C. Kleint, S. Kuzmanovski, Z. Powell, S.I. Bühring, S.G. Sander, A. Koschinsky, Organic Cu-complexation at the shallow marine hydrothermal vent fields off the coast of Milos (Greece), Dominica (Lesser Antilles) and the Bay of Plenty (New Zealand), Mar. Chem. 173 (2015) 244-252, doi:http://dx.doi.org/ 10.1016/j.marchem.2014.10.012.

[127] E.P. Achterberg, T.W. Holland, A.R. Bowie, R.F.C. Mantoura, P.J. Worsfold, Determination of iron in seawater, Anal. Chim. Acta 442 (2001) 1-14, doi: http://dx.doi.org/10.1016/S0003-2670(01)01091-1.

[128] A.P. Aldrich, C.M.G. van den Berg, H. Thies, U. Nickus, The redox speciation of iron in two lakes, Mar. Freshwater Res. 52 (2001) 885-890, doi:http://dx.doi. org/10.1071/MF00143.

[129] M. Lin, D. Pan, Y. Zhu, X. Hu, H. Han, C. Wang, Dual-nanomaterial based electrode for voltammetric stripping of trace Fe(II) in coastal waters, Talanta 154 (2016) 127-133, doi:http://dx.doi.org/10.1016/j.talanta.2016.03.060.

[130] M. Gholami, M. Rezayi, P. Moozarm Nia, I. Yusoff, Y. Alias, A novel method for fabricating $\mathrm{Fe}^{2+}$ ion selective sensor using polypyrrole and sodium dodecyl sulfate based on carbon screen-printed electrode, Measurement 69 (2015) 115-125, doi:http://dx.doi.org/10.1016/j.measurement.2015.03.030.

[131] T. Nagai, A. Imai, K. Matsushige, K. Yokoi, T. Fukushima, Short-term temporal variations in iron concentration and speciation in a canal during a summer algal bloom, Aquat. Sci. 70 (2008) 388-396, doi:http://dx.doi.org/10.1007/ s00027-008-8011-7.

[132] T. Nagai, A. Imai, K. Matsushige, T. Fukushima, Effect of iron complexation with dissolved organic matter on the growth of cyanobacteria in a eutrophic lake, Aquat. Microb. Ecol. 44 (2006) 231-239, doi:http://dx.doi.org/10.3354/ ame044231.

[133] K.N. Buck, B. Sohst, P.N. Sedwick, The organic complexation of dissolved iron along the U.S. GEOTRACES (GA03) North Atlantic Section, Deep Sea Res. Part II Top. Stud. Oceanogr. 116 (2015) 152-165, doi:http://dx.doi.org/10.1016/j. dsr2.2014.11.016.

[134] L.J.A. Gerringa, M.J.A. Rijkenberg, V. Schoemann, P. Laan, H.J.W. de Baar, Organic complexation of iron in the West Atlantic Ocean, Mar. Chem. 177 (2015) 434-446, doi:http://dx.doi.org/10.1016/j.marchem.2015.04.007.

[135] A. Mahmood, M.M. Abualhaija, C.M.G. van den Berg, S.G. Sander, Organic speciation of dissolved iron in estuarine and coastal waters at multiple analytical windows, Mar. Chem. 177 (2015) 706-719, doi:http://dx.doi.org/ 10.1016/j.marchem.2015.11.001.

[136] M. Gledhill, K.N. Buck, The organic complexation of iron in the marine environment: a review, Front. Microbiol. 3 (2012) 69, doi:http://dx.doi.org/ 10.3389/fmicb.2012.00069.

[137] T. Kim, H. Obata, Y. Kondo, H. Ogawa, T. Gamo, Distribution and speciation of dissolved zinc in the western North Pacific and its adjacent seas, Mar. Chem. 173 (2015) 330-341, doi:http://dx.doi.org/10.1016/j.marchem.2014.10.016.

[138] M.A. Saito, T.J. Goepfert, Zinc-cobalt colimitation of Phaeocystis antarctica, Limnol. Oceanogr. 53 (2008) 266-275, doi:http://dx.doi.org/10.4319/ lo.2008.53.1.0266.

[139] M.J. Ellwood, K.A. Hunter, J.P. Kim, Zinc speciation in lakes manapouri and Hayes, New Zealand, Mar. Freshwater Res. 52 (2001) 217-222, doi:http://dx. doi.org/10.1071/MF00073.

[140] A. Magnier, G. Billon, Y. Louis, W. Baeyens, M. Elskens, On the lability of dissolved $\mathrm{Cu}, \mathrm{Pb}$ and $\mathrm{Zn}$ in freshwater: optimization and application to the Deûle (France), Talanta 86 (2011) 91-98, doi:http://dx.doi.org/10.1016/j. talanta.2011.08.010.

[141] S. Meylan, N. Odzak, R. Behra, L. Sigg, Speciation of copper and zinc in natural freshwater: comparison of voltammetric measurements, diffusive gradients in thin films (DGT) and chemical equilibrium models, Anal. Chim. Acta 510 (2004) 91-100, doi:http://dx.doi.org/10.1016/j.aca.2003.12.052.

[142] P.J. Superville, E. Prygiel, A. Magnier, L. Lesven, Y. Gao, W. Baeyens, B. Ouddane, D. Dumoulin, G. Billon, Daily variations of $\mathrm{Zn}$ and $\mathrm{Pb}$ concentrations in the Deule River in relation to the resuspension of heavily polluted sediments, Sci. Total Environ. 470-471 (2014)600-607, doi:http://dx.doi.org/ 10.1016/j.scitotenv.2013.10.015.

[143] O. Baars, P.L. Croot, The speciation of dissolved zinc in the Atlantic sector of the Southern Ocean, Deep Sea Res. Part II Top. Stud. Oceanogr. 58 (2011) 2720-2732, doi:http://dx.doi.org/10.1016/j.dsr2.2011.02.003.

[144] R.W. Jakuba, M.A. Saito, J.W. Moffett, Y. Xu, Dissolved zinc in the subarctic North Pacific and Bering Sea: its distribution, speciation, and importance to primary producers, Global Biogeochem. Cycles 26 (2012) GB2015, doi:http:// dx.doi.org/10.1029/2010GB004004.

[145] M.J. Ellwood, Zinc and cadmium speciation in subantarctic waters east of New Zealand, Mar. Chem. 87 (2004) 37-58, doi:http://dx.doi.org/10.1016/j. marchem.2004.01.005.

[146] Y. Xu, F.M.M. Morel, Cadmium in marine phytoplankton, in: A. Sigel, H. Sigel, R. Sigel (Eds.), Cadmium: From Toxicity to Essentiality. Metal Ions in Life Sciences, Springer, Netherlands, Dordrecht, 2020, pp. 509-528, doi:http://dx. doi.org/10.1007/978-94-007-5179-8 16.

[147] O. Baars, W. Abouchami, S.J.G. Galer, M. Boye, P.L. Croot, Dissolved cadmium in the Southern Ocean: distribution, speciation, and relation to phosphate, Limnol. Oceanogr. 59 (2014) 385-399, doi:http://dx.doi.org/10.4319/ lo.2014.59.2.0385.

[148] S. Sander, L. Ginon, B. Anderson, K.A. Hunter, Comparative study of organic Cd and $\mathrm{Zn}$ complexation in lake waters-Seasonality, depth and $\mathrm{pH}$ dependence, Environ. Chem. 4 (2007) 410-423, doi:http://dx.doi.org/10.1071/EN07053.

[149] K.W. Bruland, Complexation of cadmium by natural organic ligands in the central North Pacific, Limnol. Oceanogr. 37 (1992) 1008-1017, doi:http://dx. doi.org/10.4319/lo.1992.37.5.1008.

[150] G. Scarponi, G. Capodaglio, G. Toscano, C. Barbante, P. Cescon, Speciation of lead and cadmium in Antarctic seawater: comparison with areas subject to different anthropic influence, Microchem. J. 51 (1995) 214-230, doi:http:// dx.doi.org/10.1006/mchj.1995.1028.

[151] L.-S. Wen, K.-T. Jiann, P.H. Santschi, Physicochemical speciation of bioactive trace metals $(\mathrm{Cd}, \mathrm{Cu}, \mathrm{Fe}, \mathrm{Ni})$ in the oligotrophic South China Sea, Mar. Chem. 101 (2006) 104-129, doi:http://dx.doi.org/10.1016/j.marchem.2006.01.005.

[152] G. Abbasse, B. Ouddane, J.C. Fischer, Determination of total and labile fraction of metals in seawater using solid phase extraction and inductively coupled plasma atomic emission spectrometry (ICP-AES), J. Anal. At. Spectrom. 17 (2002) 1354-1358, doi:http://dx.doi.org/10.1039/B203407G.

[153] Z. Bi, P. Salaün, C.M.G. van den Berg, The speciation of lead in seawater by pseudopolarography using a vibrating silver amalgam microwire electrode, Mar. Chem. 151 (2013) 1-12, doi:http://dx.doi.org/10.1016/j. marchem.2013.02.003. 
[154] M. Taillefert, C.-P. Lienemann, J.-F. Gaillard, D. Perret, Speciation, reactivity, and cycling of $\mathrm{Fe}$ and $\mathrm{Pb}$ in a meromictic lake, Geochim. Cosmochim. Acta 64 (2000) 169-183, doi:http://dx.doi.org/10.1016/S0016-7037(99)00285-9.

[155] A.R. Flegal, H. Maring, S. Niemeyer, Anthropogenic lead in Antarctic sea water, Nature 365 (1993) 242-244, doi:http://dx.doi.org/10.1038/365242a0.

[156] A. Cobelo-Garcı'a, R. Prego, Chemical speciation of dissolved copper, lead and zinc in a ria coastal system: the role of resuspended sediments, Anal. Chim. Acta 524 (2004) 109-114, doi:http://dx.doi.org/10.1016/j.aca.2004.05.085.

[157] F.L.L. Muller, Interactions of copper, lead and cadmium with the dissolved, colloidal and particulate components of estuarine and coastal waters, Mar.
Chem. 52 (1996) 245-268, doi:http://dx.doi.org/10.1016/0304-4203(95) 00097-6.

[158] X. Wang, J. Lei, S. Bi, N. Gan, Z. Wei, Determination of the speciation of aluminum(III) in natural waters by adsorption stripping voltammetry and complexation with $\mathrm{Al}^{\mathrm{III}}$-solochrome violet RS, Anal. Chim. Acta 449 (2001) 35-44, doi:http://dx.doi.org/10.1016/S0003-2670(01)01362-9.

[159] D.E. Mays, A. Hussam, Voltammetric methods for determination and speciation of inorganic arsenic in the environment-A review, Anal. Chim. Acta 646 (2009) 6-16, doi:http://dx.doi.org/10.1016/j.aca.2009.05.006. 